\title{
Assessing the utility of trace and rare earth elements as biosignatures in microbial iron oxyhydroxides
}

\author{
Christine Heim ${ }^{1 *}$, Klaus Simon ${ }^{2}$, Danny lonescu ${ }^{3,4}$, Andreas Reimer $^{1}$, Dirk De Beer ${ }^{3}$, \\ Nadia-Valérie Quéric ${ }^{1}$, Joachim Reitner ${ }^{1}$ and Volker Thiel ${ }^{1}$ \\ ${ }^{1}$ Department of Geobiology, Geoscience Centre, University of Göttingen, Göttingen, Germany \\ ${ }^{2}$ Department of Geochemistry, Geoscience Centre, University of Göttingen, Göttingen, Germany \\ ${ }^{3}$ Max-Planck-Institute for Marine Microbiology, Microsensor Research Group, Bremen, Germany \\ ${ }^{4}$ Leibnitz Institute for Freshwater Ecology and Inland Fisheries, IGB, Experimental Limnology, Stechlin, Germany
}

\section{Edited by:}

Dina M. Bower, Carnegie Institution of Washington, USA

Reviewed by:

Doug LaRowe, University of

Southern California, USA

Jakob Zopfi, University of Basel,

Switzerland

*Correspondence:

Christine Heim, Department of Geobiology, Geoscience Centre,

University of Göttingen

Goldschmidtstr. 3,

D-37077 Goettingen, Germany

e-mail: cheim@gwdg.de
Microbial iron oxyhydroxides are common deposits in natural waters, recent sediments, and mine drainage systems. Along with these minerals, trace and rare earth elements (TREE) are being accumulated within the mineralizing microbial mats. TREE patterns are widely used to characterize minerals and rocks, and to elucidate their evolution and origin. However, whether and which characteristic TREE signatures distinguish between a biological and an abiological origin of iron minerals is still not well-understood. Here we report on long-term flow reactor studies performed in the Tunnel of Äspö (Äspö Hard Rock Laboratory, Sweden). The development of microbial mats dominated by iron-oxidizing bacteria (FeOB), namely Mariprofundus sp. and Gallionella sp were investigated. The feeder fluids of the flow reactors were tapped at 183 and $290 \mathrm{~m}$ below sea-level from two brackish, but chemically different aquifers within the surrounding, $\sim 1.8 \mathrm{Ga}$ old, granodioritic rocks. The experiments investigated the accumulation and fractionation of TREE under controlled conditions of the subsurface continental biosphere, and enabled us to assess potential biosignatures evolving within the microbial iron oxyhydroxides. After 2 and 9 months, concentrations of $\mathrm{Be}, \mathrm{Y}, \mathrm{Zn}, \mathrm{Zr}, \mathrm{Hf}, \mathrm{W}, \mathrm{Th}, \mathrm{Pb}$, and $\mathrm{U}$ in the microbial mats were $10^{3}$ - to $10^{5}$-fold higher than in the feeder fluids whereas the rare earth elements and $Y$ $(R E E+Y)$ contents were $10^{4}$ - and $10^{6}$-fold enriched. Except for a hydrothermally induced Eu anomaly, the normalized REE $+Y$ patterns of the microbial iron oxyhydroxides were very similar to published REE $+\mathrm{Y}$ distributions of Archaean Banded Iron Formations (BIFs). The microbial iron oxyhydroxides from the flow reactors were compared to iron oxyhydroxides that were artificially precipitated from the same feeder fluid. Remarkably, these abiotic and inorganic iron oxyhydroxides show the same $R E E+Y$ distribution patterns. Our results indicate that the REE $+Y$ mirror closely the water chemistry, but they do not allow to distinguish microbially mediated from inorganic iron precipitates. Likewise, all TREE studied showed an overall similar fractionation behavior in biogenic, abiotic, and inorganic iron oxyhydroxides. Exceptions are $\mathrm{Ni}$ and $\mathrm{Tl}$, which were only accumulated in the microbial iron oxyhydroxides and may point to a potential utility of these elements as microbial biosignatures.

Keywords: biosignatures, microbial mats, microbial iron oxides, trace elements, rare earth elements, microbe-metal interaction, banded iron formation

\section{INTRODUCTION}

The structure, properties and formation of iron oxyhydroxides have attracted the attention of many researchers during the last decades, due to their ubiquitous occurrence in natural settings and anthropogenic biotopes, as well as their properties as an efficient sorbent for (heavy) metals, with a resulting potential for technical applications (Stumm and Morgan, 1996; Ferris et al., 2000; Cornell and Schwertmann, 2003; Katsoyiannis and Zouboulis, 2006; Michel et al., 2007; Cao et al., 2012; Chi Fru et al., 2012; Savchenko et al., 2013).

In natural environments, iron oxyhydroxide precipitates typically originate from the chemically or biologically controlled oxidation of $\mathrm{Fe}^{2+}$ to $\mathrm{Fe}^{3+}$, where the oxidation rate strongly depends on the redox conditions and the $\mathrm{pH}$ of the aqueous solution (e.g., Fortin et al., 1997; Morgan and Lahav, 2007).

Microbial precipitation of iron oxyhydroxides can be specified as 'biologically induced mineralization' (Frankel and Bazylinski, 2003). Three modes of biologically induced mineralization occur: (i) Extracellular mineral nucleation and growth are processes from which the microorganisms gain energy by direct redox conversion of specific ions like iron. (ii) Indirect mineral precipitation takes place due to gradual changes in the chemical equilibrium of the surrounding solution which may also be supported by the release of metabolic products from the microbial 
community (Thompson and Ferris, 1990; Fortin and Beveridge, 1997; Fortin et al., 1997; Southam, 2000). (iii) Passive mineralization is induced by non-living organic matter such as cell debris or extracellular polymeric substances (EPS). Thereby, exposed negatively charged surfaces act as adsorption and nucleation sites for metal cations (Urrutia and Beveridge, 1993; Anderson and Pedersen, 2003; Ercole et al., 2007; Chan et al., 2009).

While these biologically induced mineralization pathways can be well-specified in theory, they are often difficult to recognize and distinguish in natural samples (Ionescu et al., 2015b). Nevertheless, such biogenic processes may produce minerals different from their inorganically formed varieties in shape, size, crystallinity, isotopic, and trace element composition (Konhauser, 1997; Ferris et al., 1999, 2000; Weiner and Dove, 2003; Bazylinski et al., 2007; Haferburg and Kothe, 2007; Takahashi et al., 2007). In studies of contemporary mineral deposits such biosignatures may be specified and utilized for the identification of related biological processes in geological samples throughout the Earth history. Massive deposition of banded iron formations (BIFs), for instance, occurred at 2.7-2.4 Ga, after molecular oxygen started to be available due to the increasing photosynthetic activity of cyanobacteria (Anbar et al., 2007). The mechanisms of BIF formation are widely discussed and hypotheses involving abiotic and biotic processes have been proposed (e.g., Morris and Horwitz, 1983; Bau and Möller, 1993; Krapez et al., 2003; Kappler et al., 2005; Lewy, 2012). In the "biological" scenarios, a central role has been assigned to iron oxidizing bacteria $(\mathrm{FeOB})$ living under both anoxic and oxic conditions, (Konhauser et al., 2002). Therefore, studying modern microbial iron oxyhydroxides and the bacteria involved in iron oxidation are crucial for a better understanding of BIF deposition (Konhauser et al., 2002; Kappler et al., 2005).

Here we report on a flow reactor experiment investigating the development of iron-oxidizing microbial mats in the Äspö Hard Rock Laboratory (HRL). The Äspö HRL, operated by the Swedish Nuclear Fuel and Waste Management Company (SKB), is a tunnel system drilled beneath the island of Äspö in southeastern Sweden, ca. $400 \mathrm{~km}$ south of Stockholm (Figures 1A,B) and serves as a testing site for the long-term storage of nuclear waste. It offers a unique window into a subterranean terrestrial
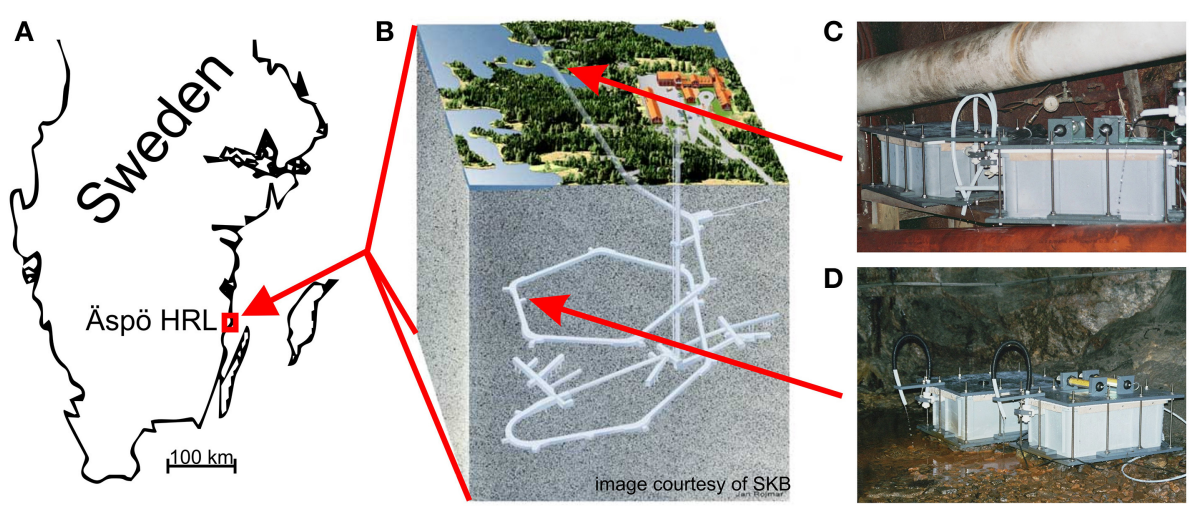

E

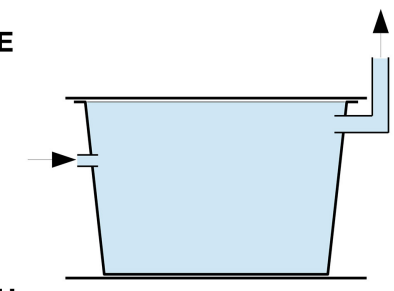

H

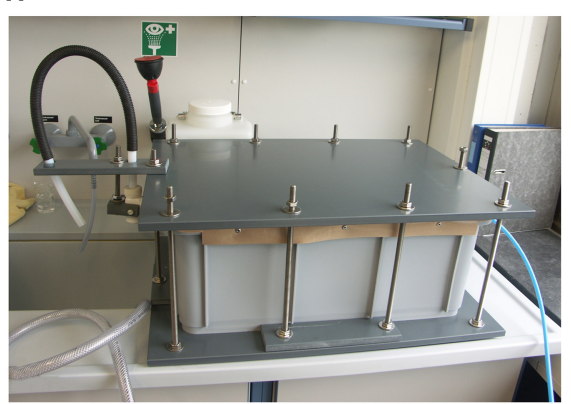

F
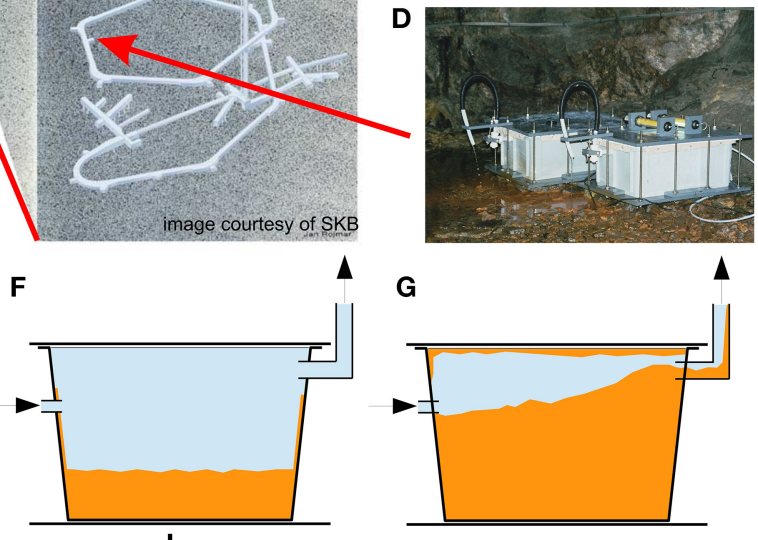

G
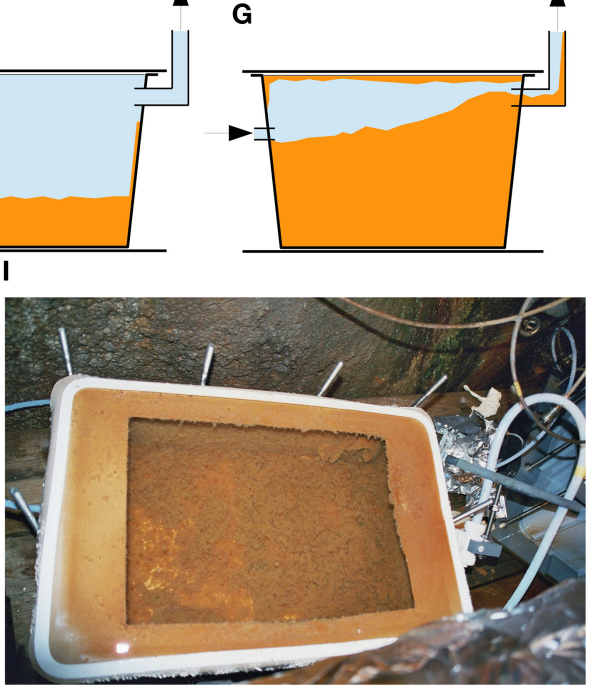

FIGURE 1 | (A) Location of the Äspö Hard Rock Laboratory (HRL); (B) 3D sketch of the HRL tunnel system beneath the island of Äspö; arrows indicate the location of the flow reactor experiments at (C) site 1327B (183 $\mathrm{m} \mathrm{bsl}$ ) and (D) site $2156 \mathrm{~B}(290 \mathrm{~m}$ bsl). (E) Sketch of a flow reactor immediately after installation, (F) with microbial mats after 2 months, and (G) with microbial mats after 9 months. (H) Flow reactor used in this study prior to installation; (I) the same flow reactor after opening, showing microbial mat development after 2 months. 
biosphere (e.g., Pedersen and Ekendahl, 1990; Pedersen, 1997, 2012; Ionescu et al., 2015a). The host rock of the Äspö site is part of the Precambrian Transscandinavian Igneous Belt and consists of $\sim 1.8 \mathrm{Ga}$ old granitic to quartz-monzodioritic rocks (Wahlgren et al., 2006).

We particularly aimed to explore microbial TREE accumulation and fractionation patterns in the microbial mats thriving in the Äspö HRL and their potential use as biosignatures for microbially induced iron precipitation. The growth of microbial consortia in the Äspö HRL strongly depends on the depth, the current velocity, salinity, oxygen content and the chemical composition of the feeder fluids supplied by different aquifers. Microbial mats thriving on tunnel walls and in ponds are often dominated by the FeOB Gallionella sp. and Mariprofundus sp. Gallionella is an autoand mixotrophic, microaerophilic $\mathrm{FeOB}$ using $\mathrm{Fe}(\mathrm{II})$ as an electron donor and $\mathrm{CO}_{2}$ or carbohydrates as carbon source (Hallbeck and Pedersen, 1991; Hallbeck et al., 1993). It lives at circum neutral $\mathrm{pH}$ and at temperatures between 5 and $25^{\circ} \mathrm{C}$. Directing the iron oxidation to twisted extracellular "stalks" made of extracellular polymeric substances (EPS), at distance from the cells, protects Gallionella ferruginea against oxygen radicals formed during the iron metabolism and consequently against encrustation of the cell surface (Hallbeck and Pedersen, 1991, 1995; Hallberg and Ferris, 2004). The production of the stalks seems to be limited to $\mathrm{pH}$ values above 6 (Hallbeck et al., 1993). G. ferruginea was first described by Ehrenberg (1836) who characterized its stalk as a unique morphological trait. However, the morphologies of Mariprofundus ferrooxidans, first described in 2007, and G. ferruginea are largely similar, as both have bean-shaped cells and winded, iron encrusted filamentous stalks (Emerson et al., 2007). M. ferrooxidans is a marine, microaerophilic lithoautotrophic $\mathrm{FeOB}$, which uses $\mathrm{Fe}(\mathrm{II})$ or $\mathrm{Fe}(0)$ as electron donor and $\mathrm{CO}_{2}$ as carbon source (Emerson et al., 2007). Studies with G. ferruginea showed that at circum neutral $\mathrm{pH}$ the size of the stalks (average $33 \mu \mathrm{m}$, maximum $60 \mu \mathrm{m}$ length) may exceed the size of the cell $(1-2 \mu \mathrm{m})$ by far (Hallbeck and Pedersen, 1991). Likewise, a stalk length of tens of $\mu \mathrm{m}$ was reported for M. ferrooxidans (Emerson et al., 2007). Both G. ferruginea and M. ferrooxidans are able to cast off, and replace, their old, encrusted stalks. Thus, the amount of iron oxyhydroxide effectively precipitated by these microorganisms may become extremely high as compared to the actual cell biomass. Therefore, these stalk-forming $\mathrm{FeOB}$ are considered as particularly relevant for iron ore and -rock forming processes throughout earth history (Konhauser et al., 2002).

Previous studies have shown that the stalk length of G. ferruginea is positively correlated not only with the amount of iron oxyhydroxides precipitated, but also with the co-precipitation of lanthanides, Th and U (Anderson and Pedersen, 2003). Here we demonstrate that microbial mat formation by $M$. ferrooxidans and G. ferruginea are also accompanied by a massive enrichment of TREE, together with the establishment of distinctive element fractionation patterns. To elucidate whether these traits may help to distinguish microbially induced from inorganically precipitated iron oxyhydroxides, the patterns found in the microbial mats were compared to those obtained by abiotic/inorganic precipitation from the same feeder fluids, and also to TREE distributions reported for ancient BIF deposits.

\section{MATERIALS AND METHODS FLOW REACTORS}

A flow reactor experiment was designed to simulate the environmental conditions in fluid conduits within the granodioritic host rock and investigate microbial iron biomineralization and TREE accumulation under monitored conditions. Dark, air-tight flow reactors (total volume $45 \mathrm{l}$ ) non-pressurized and with a flow of $0.7 \mathrm{l} / \mathrm{min}$ were constructed (Figures $\mathbf{1 B}-\mathbf{F}$ ) and connected to the aquifers in the Äspö HRL in 2006. Only chemically inert materials such as polytetrafluoroethylene (PTFE, Teflon ${ }^{\circledR}$ ), PTFE—fiber glass, fluorinated ethylene propylene (FEP) and special PTFEfoam were used as construction materials to avoid chemical contamination from glass and plastic ware. The flow reactor systems and connection tubing's were thoroughly sterilized with ethanol (70\%, overnight) before underground installation to prevent biological contamination from the surrounding environment.

The geochemistry of feeder fluids was studied at the different tunnel levels prior to setup of the flow reactors to select suitable installation sites. According to the results, and considering published data (Ferris et al., 1999; Laaksoharju et al., 1999; SICADA database ${ }^{1}$ ), the flow reactors were connected to aquifers at $183 \mathrm{~m}$ (site 1327B) and $290 \mathrm{~m}$ below sea level (site 2156B) (Figures 1B-D). The former shows a major influence of recent Baltic Sea water, whereas the latter contains a mixture of recent and ancient Baltic Sea water (retention time of 4-6 years), and glacial melt water (Laaksoharju et al., 1999). The specially designed outlet enabled an operation of the flow reactors without any headspace.

During the experiment the reactors were kept strictly undisturbed, except for sampling of reactor water and microbial mats after 2 and 9 months, respectively. The reactors were regularly controlled for maintenance/tightness, and in- and outflowing waters were routinely sampled and analyzed for physicochemical fluctuations.

\section{Artificial precipitation experiments}

As a reference, artificial precipitation experiments were performed using 301 of aquifer water sampled from site 1327B that was split into three aliquots (i-iii), as follows. (i) To study the abiotic precipitation of iron oxyhydroxides, i.e., without any influence of living organisms, a $10 \mathrm{l}$ aliquot was treated immediately after sampling with concentrated and distilled $\mathrm{HNO}_{3}$ (Merck, triple distilled in the GZG geochemistry lab, purity***) to kill the microbial content (final concentration $2 \% \mathrm{HNO}_{3}$ ). However, tests with other, parallel samples showed that the $\mathrm{HNO}_{3}$ treatment does not destroy the microbial EPS, which may also contribute to the precipitation of iron oxyhydroxides. (ii) Therefore, to assess the inorganic precipitation of iron oxyhydroxides, without any influence of both, living cells as well as dead biomass, concentrated and distilled $\mathrm{HNO}_{3}$ and $\mathrm{H}_{2} \mathrm{O}_{2}$ (Sigma-Aldrich, 35\%) was used for the second aliquot to kill the microorganisms and oxidize all organic matter. In aliquots (i) and (ii), iron oxide precipitation was initiated by addition of $\mathrm{NH}_{4} \mathrm{OH}$. (iii) As a biotic (living) control, the third 101 aliquot was closed

\footnotetext{
${ }^{1}$ SICADA. Database of the Swedish organisation for nuclear fuel and waste management (SKB), owner of the Äspö HRL. See also www.skb.se.
} 
and kept at the temperature of the sampling site $\left(15^{\circ} \mathrm{C}\right)$ for 15 days, thus enabling microbial iron oxidation to proceed.

The iron oxides precipitated from the three aliquots were separated from the aquifer water by centrifugation. The precipitates were washed three times with deionized water to remove the salt content. Afterwards the samples were lyophilized and weighed. A fraction was analyzed for the organic carbon $\left(\mathrm{C}_{\text {org }}\right)$ content of the precipitates. For TREE analysis the lyophilized precipitates were processed like the microbial mat samples, as described below.

\section{MICROBIOLOGICAL DIVERSITY \\ DNA extraction}

Biofilm matter was collected in sterile $50 \mathrm{ml}$ tubes. After centrifugation in the field lab shortly after collection, the samples were frozen at $-20^{\circ} \mathrm{C}$ until further processing. After thawing in the home laboratory, the samples were resuspended (to $50 \mathrm{ml}$ ) in an iron dissolution solution ( $0.35 \mathrm{M}$ acetic acid; $0.2 \mathrm{M}$ sodium citrate; $25 \mathrm{mM}$ sodium dithionite; Thamdrup et al., 1993). The cleaned cells (and remaining iron precipitates) were filtered onto polycarbonate filters and washed with $1 \mathrm{X}$ PBS. DNA was extracted using the hot-phenol method as described elsewhere (Ionescu et al., 2012).

\section{Pyrosequencing}

DNA samples were sent for Roche 454 pyrosequencing at the MrDNA lab (Shallowater, TX, USA). Sequencing of the $16 \mathrm{~S}$ rRNA gene was done using the $28 \mathrm{~F}$ and $519 \mathrm{R}$ general primers (Lane, 1991). 374,666 sequences were obtained and were processed as described in Ionescu et al. (2012). Shortly, the sequences were checked for quality (length, homopolymers, and ambiguous bases) and aligned against the SILVA reference database. Sequences with poor alignment score were removed while the rest was clustered (per sample) into operational taxonomic units (OTUs) at a similarity value of $98 \%$. Reference sequences of each OTU ware assigned a taxonomy using BLAST against the SILVA ref database (Version 111; Quast et al., 2013). Full OTU mapping of the sample was done by clustering the reference sequences of each OTU at 99\% similarity. The sequences were deposited at the European Nucleotide Archive (ENA) under study accession number PRJEB4914 (http://www.ebi.ac.uk/ena/data/view/ PRJEB4914).

\section{CHEMICAL ANALYSIS}

Oxygen in the feeder fluids was measured using the Winkler method (Hansen, 1999). Conductivity and $\mathrm{pH}$ were determined together with anion measurements by titration and ion chromatography. Spectrophotometrical $\mathrm{Fe}_{\text {total }} / \mathrm{Fe}$ (II) measurements were performed on acidified samples immediately after sampling on-site by the certified SKB chemistry lab. TREE were analyzed using Inductive Coupled Plasma Mass Spectrometry (ICP-MS; Perkin Elmer SCIEX Elan DRCII) and Optical Emission Spectroscopy (ICP-OES; PerkinElmer Optima 3300 DV). For sample conservation and TREE measurements, concentrated $\mathrm{HNO}_{3}$ (Merck, triple distilled in GZG geochemistry lab, purity ${ }^{* * *}$ ) was added to $50 \mathrm{ml}$ water samples (final concentration $2 \% \mathrm{HNO}_{3}$ ). After sampling, the microbial mats were frozen, transported in dry ice, and stored at $-20^{\circ} \mathrm{C}$ until analysis. To quantify REE in the mineral precipitates, $4 \mathrm{ml}$ of $\mathrm{H}_{2} \mathrm{O}_{2}(35 \%)$ and $2 \mathrm{ml}$ of concentrated, distilled $\mathrm{HNO}_{3}$ were added to $500 \mathrm{mg}$ of lyophilized sample. The resulting solutions of the mineral precipitates were diluted in $50 \mathrm{ml}$ of deionized water (final concentration $4 \% \mathrm{HNO}_{3}$ ). These solutions, a reference sample (matrix matched calibration solution) containing all chemicals used, and the water samples were spiked with internal Ge, Rh, In and Re standards and analyzed by ICP-MS and ICP-OES. The data obtained were mean values of triple measurements. The internal reproducibility was better than $2 \%$. External accuracy was checked by measuring and comparing to international standard reference materials (GJA-2, Japanese Andesite). Furthermore, the results were drift corrected by monitoring one calibration point through the course of the run, and also corrected for the major oxygen interferences ( $\mathrm{BaO}, \mathrm{REEO}$, etc.). For a better comparison between the different sites and ages, the TREE data were normalized on the respective feeder fluids (Figures 5, 6, 8). To enable a comparison with data from other publications the TREE data are normalized on PAAS (Figure 7; Post-Archaean average Australian sedimentary rock; McLennan, 1989).

Carbon $\left(\mathrm{C}_{\text {tot }}\right)$, total nitrogen $\left(\mathrm{N}_{\text {tot }}\right)$, and sulfur $\left(\mathrm{S}_{\text {tot }}\right)$ were analyzed using a CNS Elemental Analyzer (HEKAtech Euro EA). Inorganic carbon $\left(\mathrm{C}_{\text {inorg }}\right)$ and organic carbon $\left(\mathrm{C}_{\text {org }}\right)$ were analyzed with a Leco RC 412 multiphase carbon analyzer. Duplicate measurements were performed routinely, and appropriate internal standards were used for the $\mathrm{C}_{\text {inorg }}$ (Leco 502030), $\mathrm{C}_{\text {org }}$ (Leco 501-034), and CNS (2,5-Bis(5-tert-butyl-2benzoxazolyl)thiophene, SA990752; atropine sulfate SA990753; IVA Analysentechnik) analyses.

\section{SCANNING ELECTRON MICROSCOPY AND ENERGY DISPERSIVE X-RAY ANALYSIS (SEM-EDX)}

For SEM-EDX analysis, samples were fixed in $2 \%$ glutardialdehyde immediately after sampling and stored at $4^{\circ} \mathrm{C}$. Prior to analysis, the samples were dehydrated in rising ethanol concentration, by rinsing with successive solutions of $15,30,50,70 \%$ ethanol (30 min each), followed by 90 and $99 \%$ (60 min each), and $99 \%$ ethanol $(12 \mathrm{~h})$. After the dehydration series, the samples were mounted on SEM sample holders and sputtered with Au-Pd $(7.3 \mathrm{~nm}$ for $120 \mathrm{~s})$. Samples were analyzed using a field emission SEM (LEO 1530 Gemini) combined with an INCA X-act EDX (Oxford Instruments).

\section{RESULTS}

\section{FEEDER FLUID CHEMISTRY}

Basic water chemistry data for the feeder fluids are given in Table 1. Replicate analyses (data not shown) revealed that their chemical properties remained virtually stable over 15 months, i.e., over the total duration of the experiments (STD, $2 \sigma$, below $10 \%$ ). The feeder fluids consisted of waters with salinities of $5.8 \%$ at site 1327B (183 $\mathrm{m} \mathrm{bsl})$, and $7 \%$ at site $2156 \mathrm{~B}$ (290 m bsl). Oxygen measurements revealed stable $\mathrm{O}_{2}$-concentrations between 0.28 and $0.38 \mathrm{mg} / \mathrm{l}$ in the feeder fluids and thus, suboxic conditions. The fluid at the shallower site, being influenced by recent Baltic Sea water, contained higher amounts of sulfate and showed a higher alkalinity than the fluid from the deeper site. At both sites, Fe in the feeder fluids was exclusively present as ferrous iron 
Table 1 | Basic chemical parameters of the feeder fluids and Baltic Seawater (for comparison).

\begin{tabular}{|c|c|c|c|c|c|c|c|c|c|c|c|}
\hline & pH & $\begin{array}{l}\text { Cond. } \\
\mathrm{mS} / \mathrm{m}\end{array}$ & $\begin{array}{l}\mathrm{HCO}_{3}^{-} \\
{[\mathrm{mg} / \mathrm{ll}]}\end{array}$ & $\begin{array}{c}\mathrm{Cl}^{-} \\
{[\mathrm{mg} / \mathrm{l}]}\end{array}$ & $\begin{array}{c}\mathrm{Br}^{-} \\
{[\mathrm{mg} / \mathrm{l}]}\end{array}$ & $\begin{array}{c}F^{-} \\
{[\mathrm{mg} / \mathrm{l}]}\end{array}$ & $\begin{array}{c}\mathrm{SO}_{4}^{2-} \\
{[\mathrm{mg} / \mathrm{I}]}\end{array}$ & $\begin{array}{l}\text { Sulfide } \\
\text { [mg/l] }\end{array}$ & $\begin{array}{l}\mathrm{Fe}_{\text {total }} \\
{[\mathrm{mg} / \mathrm{l}]}\end{array}$ & $\begin{array}{c}\mathrm{Fe}^{2+} \\
{[\mathrm{mg} / \mathrm{I}]}\end{array}$ & $\begin{array}{c}\mathrm{O}_{2} \\
{[\mathrm{mg} / \mathrm{I}]}\end{array}$ \\
\hline 1327B feeder fluid & 7.33 & 978 & 209 & 3059 & 14.3 & 1.54 & 425 & 0.07 & 1.69 & 1.68 & 0.28 \\
\hline Baltic Sea water & 6.90 & 278 & 26 & 692 & 2.4 & 0.42 & 501 & 2.98 & 0.57 & 0.34 & 3.47 \\
\hline
\end{tabular}

Mean values (<10\% STD) obtained from replicate sampling over the duration of the experiment. Cond., conductivity.
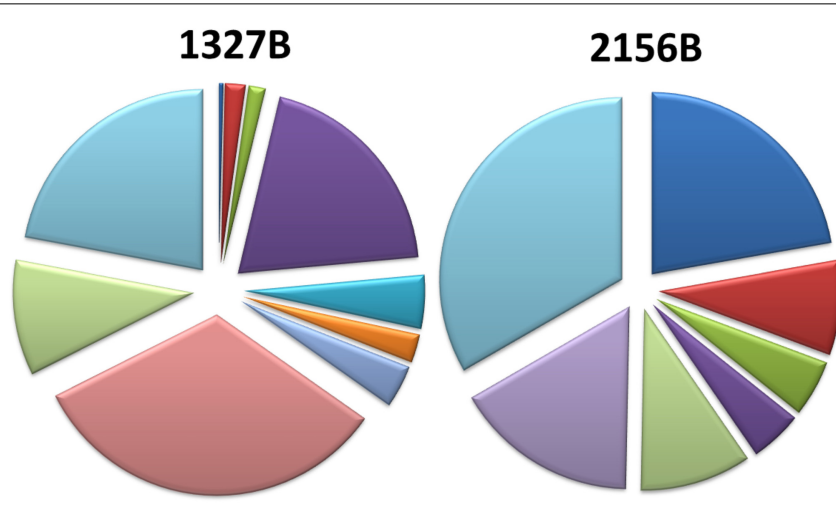

$\square$ Filomicrobium
$\square$ Hyphomicrobium
$\square$ Pedomicrobium
$\square$ Paracoccus
$\square$ Acidovorax
$\square$ Gallionella
$\square$ Sideroxydans
$\square$ uncult. Gallionellaceae
$\square$ Acidiferrobacter
$\square$ Thermomonas
$\square$ Mariprofundus

FIGURE 2 | Composition of the microbial communities performing iron-oxidation or being involved in the deposition of iron oxyhydroxides in the mats. At site 1327B, main FeOB were Mariprofundus sp. and Gallionellaceae, whereas at site 2156B Mariprofundus sp. dominated and Gallionellaceae were absent.

$\left(\mathrm{Fe}^{2+}\right.$, Table 1$)$. The $\mathrm{Fe}^{2+}$ concentration was considerably higher at site $1327 \mathrm{~B}(1.68 \mathrm{mg} / \mathrm{l})$ than at site $2156 \mathrm{~B}(0.59 \mathrm{mg} / \mathrm{l})$.

\section{MICROBIAL MAT DEVELOPMENT}

Within 2 months, several cm-thick microbial mats developed in both flow reactors (Figures 1F,I). Macroscopically, the mats consisted of ochrous, fluffy material. Sequencing data revealed that the shallower flow reactor contained Mariprofundus sp. and Gallionella-like organisms as the dominating FeOB, whereas the deeper flow reactor contained Mariprofundus sp. but not G. ferruginea (Figure 2). Other iron oxidizers detected in both reactors were Paracoccus sp., Acidithioacillus sp., Leptothrix sp., Thiobacillus sp., and Sideroxydans sp.

After 9 months, both flow reactors were almost completely filled with microbial mats which showed a massive abundance of stalks characteristic of Mariprofundus sp. and G. ferruginea (Figure 3A). These stalks showed a delicate filamentous structure with only few mineral precipitates after 2 months (Figure 3B). After 9 months, the flow reactors at both sites still exhibited macroscopically similar microbial mats, but in both cases the FeOB stalks were extensively encrusted with mineral precipitates (Figure 3C). XRD measurements showed two broad humps with maxima between 25 and $70^{\circ} 2 \theta$, indicating two-line ferrihydrite as dominating mineral form (data not shown). Although microbially formed ferrihydrites are relatively stable mineral phases (Kennedy et al., 2004; Toner et al., 2012), their water content may vary (Schwertmann et al., 1999), and we therefore use the comprehensive term "iron oxyhydroxides" hereafter. Further, SEM/EDX investigations revealed the presence of authigenic gypsum crystals (Figure 3D).
The organic carbon concentrations of the microbial mats remained fairly constant during the experiment and did not exceed $3.7 \%$ dry weight at site $2156 \mathrm{~B}$ and $7 \%$ dry weight at site $1327 \mathrm{~B}$ (Table 2). At both sites, the content of nitrogen remained stable at $0.3 \%$ dry weight. Carbon phases analysis indicated that $\mathrm{C}_{\text {inorg }}$ (Table 2) was bound as siderite in the young as well as in the aged microbial mats at both sites.

\section{TREE ACCUMULATION AND FRACTIONATION WITHIN THE MICROBIAL MATS}

The concentrations of all cations analyzed in the feeder fluids and in the microbial mats are given in Table 3. In both flow reactors, the main element patterns of the microbial mats were always dominated by iron (Figure 4). Other main elements, such as $\mathrm{Al}, \mathrm{Si}, \mathrm{Na}, \mathrm{Ca}$, and $\mathrm{Mg}$ showed considerably different relative amounts at both sites after the initial 2 months period (Figures 4A,C). After 9 months, however, $\mathrm{Si}, \mathrm{Na}, \mathrm{Ca}$, and $\mathrm{Mg}$ approached similar abundances (Figures 4B,D). The bivariate plots provided in Figure 5 illustrate the relative element accumulation in the microbial mats normalized on the feeder fluid over 2 and 9 months. Compared to the feeder fluids, the microbial mats showed accumulations of most TREE. In both flow reactors, the REE and the trace elements $\mathrm{Be}, \mathrm{Y}, \mathrm{Zr}, \mathrm{Nb}, \mathrm{Hf}, \mathrm{Pb}$, Th, and $\mathrm{W}$ were $10^{3}-10^{4}$-fold enriched after 2 months. After 9 months, these elements showed up to $10^{6}$-fold enrichments (Figure 5). In contrast, $\mathrm{Ca}, \mathrm{Na}, \mathrm{Mg}$, and $\mathrm{K}$ did not accumulate during the first 2 months in the mats though these elements were available at high concentrations in the feeder fluids. The accumulation of these elements in both flow reactors was only observed after 9 months and was most likely related to gypsum precipitation (Figures 3D, 4D, 5). 

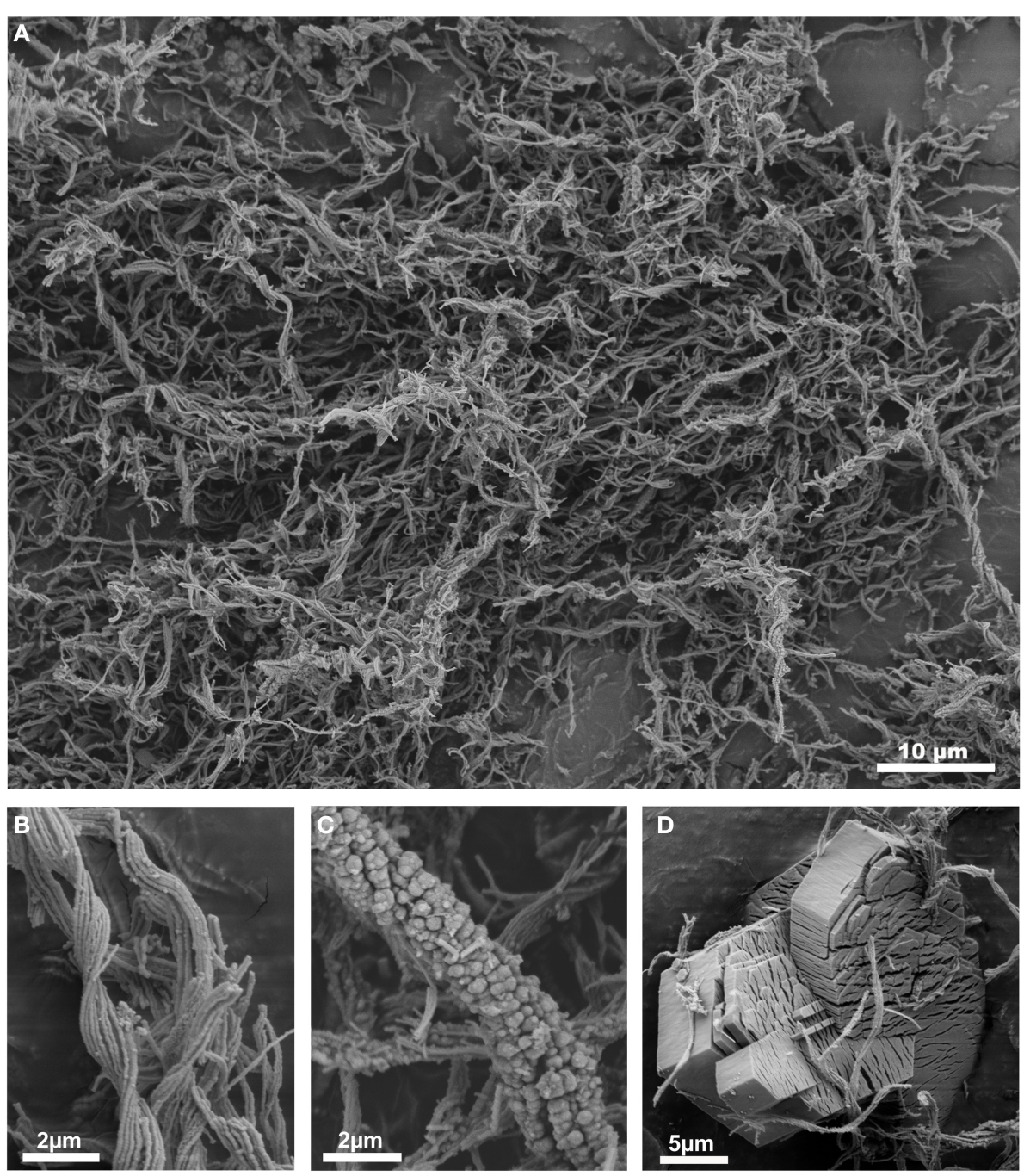

FIGURE 3 | (A) SEM micrograph of the 2 months old microbial mat from the flow reactor at site 1327B, showing the twisted EPS-stalks of Gallionella sp. and/or Mariprofundus sp. (B) Detail of young EPS-stalks sampled after 2 months, still showing a pristine filamentous structure; (C) Aged EPS-stalks sampled after 9 months, showing heavy iron oxyhydroxide impregnation; (D) authigenic gypsum crystals in a 9 months old microbial mat.

Table 2 | Concentrations $\left(\%_{\text {dry weight }}\right)$ of organic carbon $\left(\mathrm{C}_{\text {org }}\right)$, inorganic carbon $\left(\mathrm{C}_{\mathrm{inorg}}\right)$, total nitrogen $\left(\mathrm{N}_{\text {tot }}\right)$, and total sulfur $\left(\mathrm{S}_{\text {tot }}\right)$ in the mineralized microbial mats after 2 and 9 months, respectively.

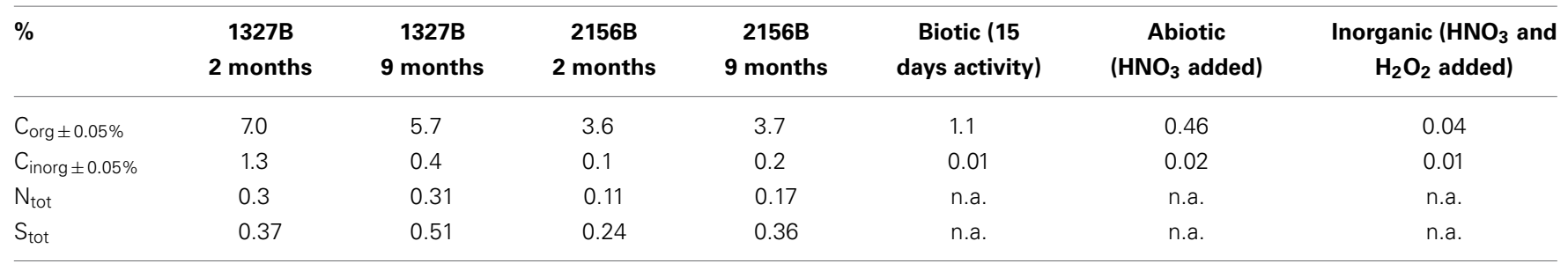

$C_{o r g}$ and $C_{\text {inorg }}$ values of the iron oxyhydroxides from the artificial precipitation experiment. n.a., not analyzed.

At both sites, REE $+\mathrm{Y}$ patterns of the microbial mats plotted against the feeder fluids showed a nearly consistent $10^{4}$-fold ( 2 months) and $10^{6}$-fold (9 months) accumulation of these elements (Figure 6). However, minor anomalies were observed for $\mathrm{Eu}, \mathrm{Y}, \mathrm{Yb}$ and $\mathrm{Lu}$, and the rate of accumulation was somewhat higher at site 2156B compared to site 1327B. The Fe normalized REE values from 1327B showed an increasing REE accumulation with the iron oxyhydroxides during the first 2 months, and a significant drop during the 9 months period. At 2156B the Fe normalized REE uptake with the iron oxyhydroxides was 
Table 3 | TREE concentrations of the feeder fluids and in the iron oxidizing microbial mats after $\mathbf{2}$ and 9 months, respectively.

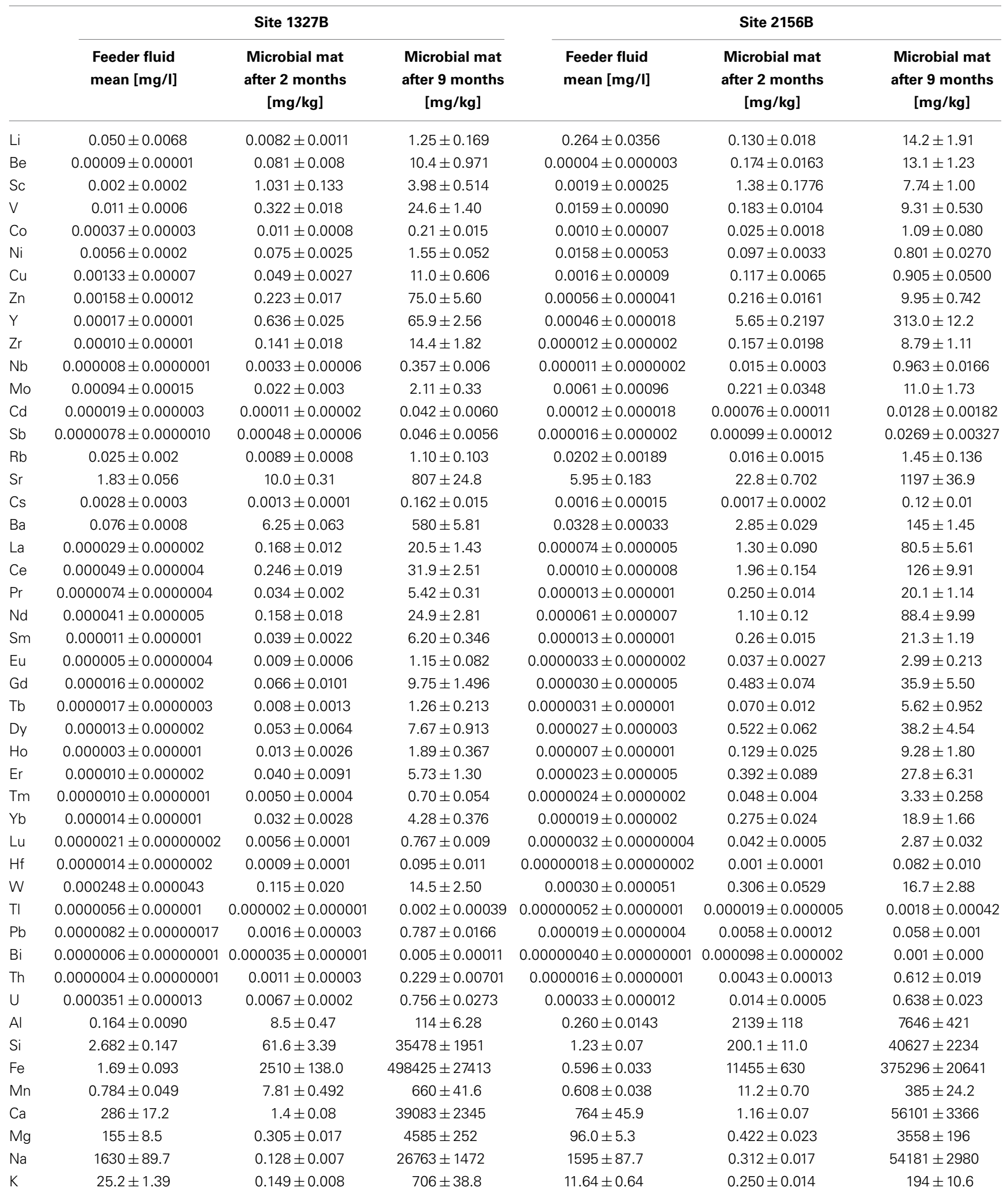




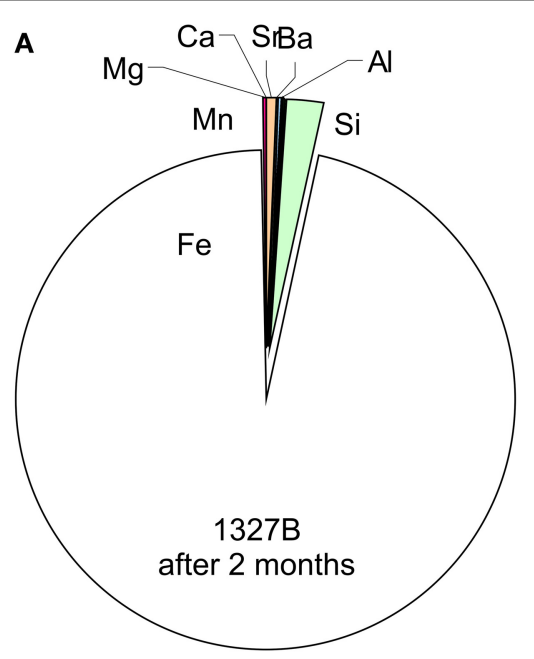

B
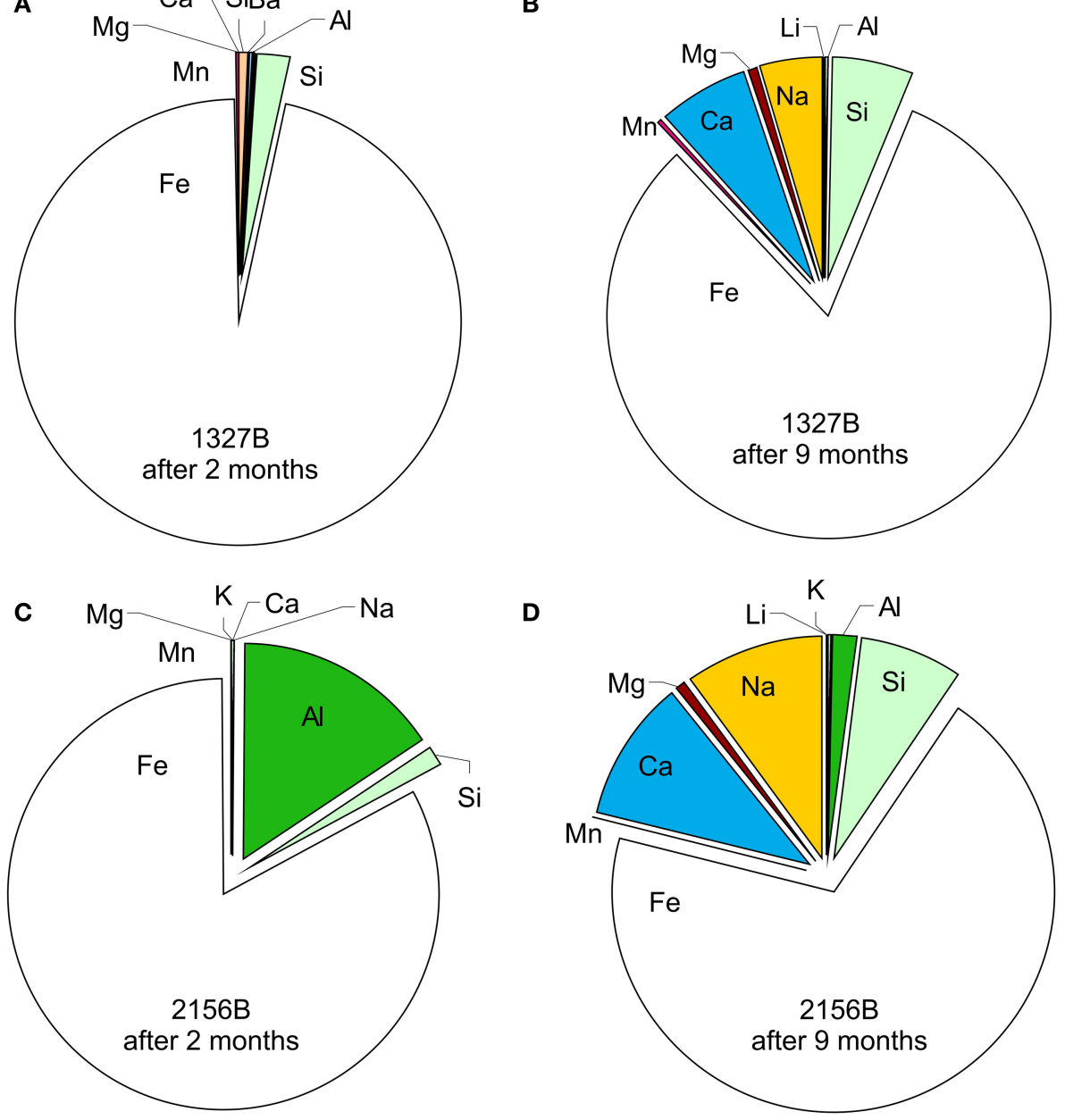

FIGURE 4 | Distribution of the major cations within the mineralized microbial mats after 2 months (A, C) and 9 months (B, D), respectively. Note the convergence of the major element patterns over time, although the mats were fed by chemically differing fluids.

almost negligible, even decreased for some of the REE during the 2 months period. During the 9 months period, however, a considerable accumulation of REE was observed.

\section{TREE ACCUMULATION AND FRACTIONATION IN ARTIFICIAL PRECIPITATES}

The REE $+Y$ patterns resulting from artificial (i.e., inorganic, abiotic, and biotic) mineral precipitation using aquifer water from sites $1327 \mathrm{~B}$ and $2156 \mathrm{~B}$ are given in Figure 7. The data reveal a great similarity between these REE+Y-patterns, and with those obtained from the microbial mats and the aquifer waters. Apart from the similarity in $\mathrm{REE}+\mathrm{Y}$ distributions, however, we observed that the trace elements $\mathrm{Ni}, \mathrm{Cd}$ and $\mathrm{Tl}$ were below detection limit in the inorganic precipitate (Figure 8). Ni and $\mathrm{Tl}$ were also missing in the abiotic precipitate. Only $\mathrm{Tl}$ was absent from the 15 days biogenic precipitates whereas both $\mathrm{Ni}$ and $\mathrm{Cd}$ were clearly detected (Figure 8). Molybdenum (Mo) concentrations in the artificial experiments were very low and were in the range of the measurement uncertainty; therefore they will not be discussed further.

\section{DISCUSSION}

The microbial mats and the mineral precipitates formed during the flow reactor experiment showed distinct changes in their morphological structure as well as in their elemental composition over time (Figures 3B,C, 4A-D, 5A,B). Interestingly, however, the major chemical traits of both microbial mats converged with time, although both study sites were spatially separated from each other and showed a different composition of their microbial communities. As the feeder fluid compositions did not change considerably during the experiment, these chemical changes may be attributed to processes occurring within the microbial mats. In the following sections, these processes will be interpreted with respect to their biotic or inorganic nature.

After 2 months most of the EPS-stalks still showed a delicate structure of twisted filaments and only few iron oxyhydroxide precipitates outside the stalks, but the TREE and Fe accumulation within these microbial mats already exhibited a $10^{4}$-fold accumulation normalized on the feeder fluid. It has been proposed that during the iron oxidation process in young G. ferruginea stalks, initial mineralization of hematite $\left(\mathrm{Fe}_{2} \mathrm{O}_{3}\right)$ takes place within the 


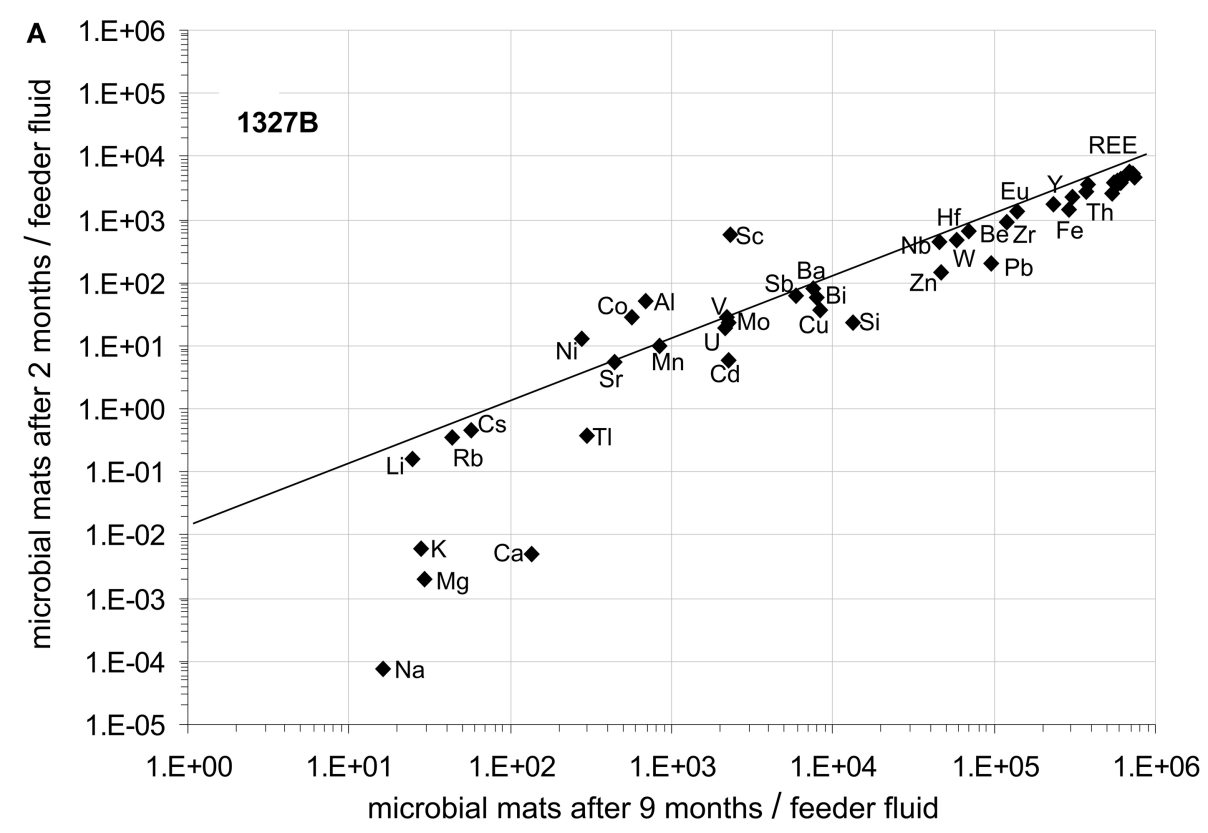

B

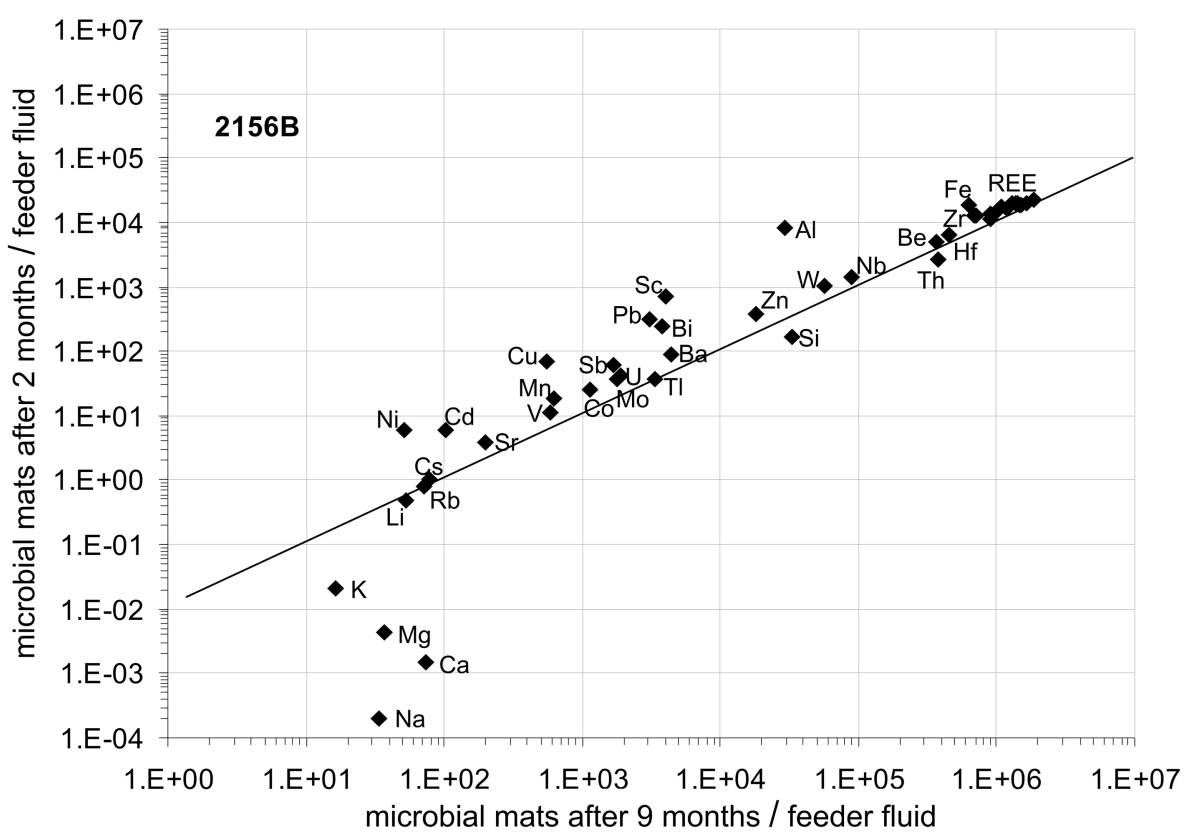

FIGURE 5 | Bivariate plots of TREE accumulation of the mineralized microbial mats after 2 and 9 months with respect to the inflowing water, (A) at site 1327B, and (B) at site 2156B. At both sampling intervals and at both sites, highest accumulation rates were observed for $\mathrm{REE}, \mathrm{Be}, \mathrm{Y}$,
$\mathrm{Zr}, \mathrm{Nb}, \mathrm{Hf}, \mathrm{Pb}$, Th, and $\mathrm{W}$, whereas $\mathrm{Ca}, \mathrm{Na}, \mathrm{Mg}$, and $\mathrm{K}$ accumulated only in low amounts, and only in the 9 months old microbial mats. The accumulation of the latter elements is attributed to gypsum precipitation occurring in the aged mats (Figure 3D). filaments, whereas aging stalks increasingly precipitate iron oxyhydroxides outside the filaments (Hallberg and Ferris, 2004). Indeed, studies have shown that Mariprofundus sp. and G. ferruginea are capable of controlling the iron mineralization process through localizing the biotic and abiotic mineral precipitation (Saini and Chan, 2013). The stalk surfaces were observed to be smooth and pristine during the initial stage of formation, but with increasing distance from the cell (i.e., age) they became more and more coated with lepidocrocite $(\mathrm{FeOOH})$ and two-line ferrihydrite (Chan et al., 2011). In our experiments, observations of still pristine stalks, with only minor mineral deposits on their surfaces (Figure 3B), are in good agreement with a controlled iron oxidation process that occurred mainly within the stalks at an early stage of mineralization (Hallberg and Ferris, 2004; Comolli et al., 2011). The presence of hematite, as previously described as an early internal precipitate for Gallionella 


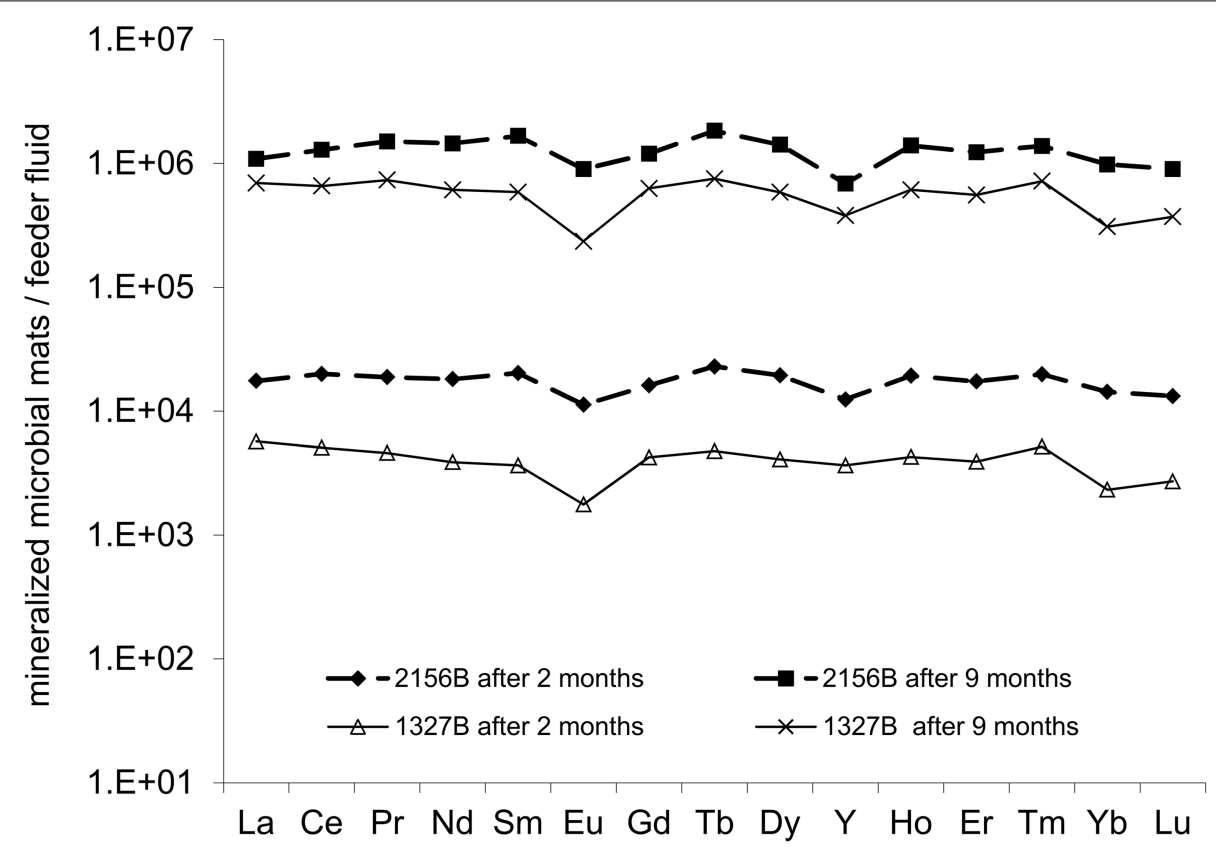

FIGURE 6 | Plot illustrating the REE+Y fractionation in the microbial iron oxyhydroxides. Nearly uniform REE $+Y$ patterns, except for minor negative Eu and $Y$ anomalies, indicate a largely radius-independent fractionation of $R E E+Y$ from the respective feeder fluids.

stalks (Hallberg and Ferris, 2004), was not observed in our study.

Our finding that the accumulation rates of REE, Be, Y, Zr, $\mathrm{Nb}, \mathrm{Hf}, \mathrm{Pb}, \mathrm{Th}$, and $\mathrm{W}$ in the microbial mat mineral precipitates were as high as those of $\mathrm{Fe}$ (Figures 5A,B) points toward a coprecipitation of these elements due to scavenging by the iron oxyhydroxides. This process is sustained by the strong metal sorption capacity of iron oxyhydroxides, which is widely used in technical applications and remediation activities (Dzombak and Morel, 1990; de Carlo et al., 1998; Bau, 1999; Cornell and Schwertmann, 2003; Michel et al., 2007). Laboratory studies on the properties of inorganic iron oxyhydroxides as metal sorbents have demonstrated their strong accumulation capacities for REE+Y (de Carlo et al., 1998; Bau, 1999). These studies also showed that the sorption of REE $+\mathrm{Y}$ onto iron oxyhydroxides increases strongly, up to $10^{4}$-fold, with increasing $\mathrm{pH}$. Furthermore, metal ions with a higher positive charge tend to show enhanced biosorption, independently of the absolute amount of metals present (Haferburg et al., 2007), which plausibly explains the strong enrichments observed for the three-and four-valent elements $\mathrm{Al}$ and $\mathrm{Si}, \mathrm{REE}, \mathrm{Y}$, $\mathrm{Zr}, \mathrm{Hf}, \mathrm{Pb}$, Th, and $\mathrm{W}$ (Figure 5). Furthermore, Si adsorption to iron oxyhydroxides increases with $\mathrm{pH}$ and with higher concentration will lead to surface precipitation of $\mathrm{SiO}_{2}$ and coating of iron oxyhydroxides (Cornell and Schwertmann, 2003). Si and organic matter may be important factors that influence the precipitation of iron oxyhydroxides (Toner et al., 2012). The significant accumulation of $\mathrm{Al}$ especially in the 2 months old microbial mat from 2156B might relate to the presence of iron-reducing and fermentative bacteria in the mats (Ionescu et al., 2015a,b) which are known to selectively mobilize iron oxides and silica under anaerobic conditions. In soils, these processes induce an enrichment of $\mathrm{Al}$ in the residual matter which may ultimately lead to the formation of bauxite (Gadd, 2010).

$\mathrm{REE}+\mathrm{Y}$ are consistently accumulated in the microbial mats (Figure 6), with the patterns of the aquifers being preserved in the iron oxyhydroxides at a $10^{6}$-fold enrichment. This observation implies that fractionation of REE $+Y$ from the feeder fluids and incorporation in, or sorption to, the iron oxyhydroxides is a radius-independent process, as it has been observed in artificial precipitation experiments (Bau, 1999). Other studies have shown that REE accumulation can be closely correlated to the increasing stalk length of $G$. ferruginea, whereas the enrichments of actinides like $U$ and Th show a less pronounced correlation (Anderson and Pedersen, 2003). The different behavior of the latter may be explained by their particularly high sorption susceptibility to organic matter (e.g., Lin et al., 2014). Consequently, not only the iron oxyhydroxide precipitates, but also the organic matter of the stalks most likely play a crucial role in TREE precipitation within "young" microbial mats, because the EPS offers large reactive surfaces for metal sorption. According to this scenario, the ongoing incrustation of the stalks of Mariprofundus sp. and Gallionella sp. (Figure 3C) most likely caused a gradual decline of exposed EPS-surfaces, and thus reduced the passive mineralization capacities of the microbial mats. Instead, indirect mineral precipitation became increasingly important in the course of the experiment, and probably accounted for the significantly higher accumulations of $\mathrm{Si}$ and the lower valent cations Cs, Sr, Se, Li observed in the aged microbial mats (Figure 4).

The entire water chemistry data of the aquifers were used to calculate saturation indices (SI). SI values calculated for gypsum using PhreeqC range between -0.74 and -0.95 , indicating that 


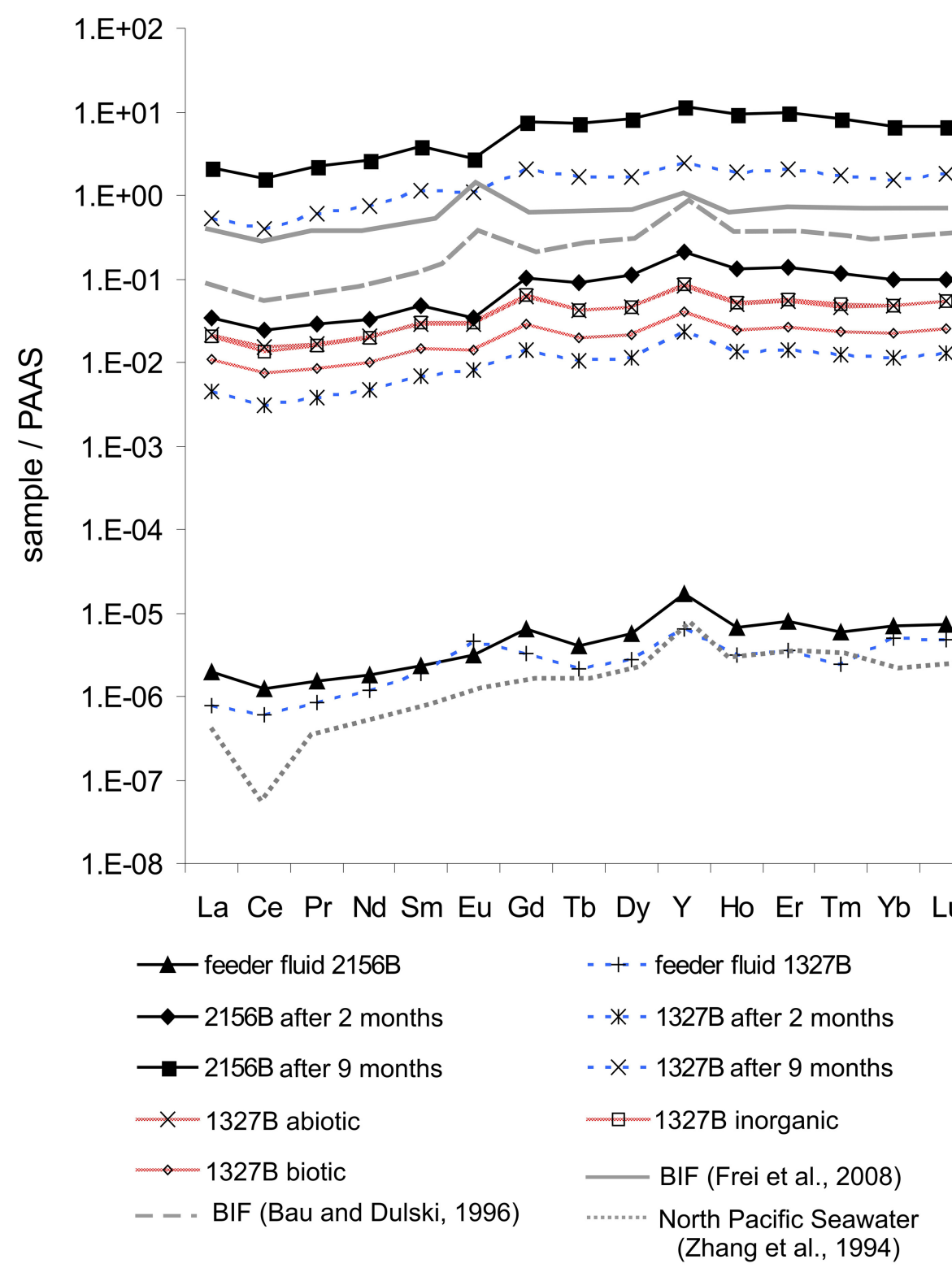

FIGURE 7 | Comparison of PAAS-normalized (Post-Archaean average Australian sedimentary rock; McLennan, 1989) REE $+Y$ patterns of the microbial iron oxyhydroxides from all flow reactors and the artificial precipitation experiments from the feeder fluid at site 1327B, in comparison to published data for modern seawater and BIFs. Note the similarity between all REE+Y-patterns regardless of a biological contribution. direct gypsum precipitation from the aquifers is rather unlikely. Hence, the authigenic formation of gypsum observed in the microbial mats (Figure 3D) can only be explained by microenvironments inducing local supersaturation of $\mathrm{Ca}^{2+}$ and $\mathrm{SO}_{4}^{2-}$. The 9 months old microbial mats were quite thick and dense (Figure 1G) which hampered the fluid circulation in the reactors and likely gave rise to the formation of micro-environments. The creation of such micro-environments may also be promoted by sulfur oxidizing bacteria (SOB) which oxidize hydrogen sulfide $\left(\mathrm{H}_{2} \mathrm{~S}\right)$ to sulfur intermediates [i.e., elemental sulfur $\left(\mathrm{S}^{\circ}\right)$, thiosulfate $\left(\mathrm{S}_{2} \mathrm{O}_{3}^{2-}\right)$, sulfite $\left.\left(\mathrm{SO}_{3}^{2-}\right)\right]$ and eventually, sulfate $\left(\mathrm{SO}_{4}^{2-}\right)$. Indeed, several SOB genera (Thiothrix, Thiobacillus,
Sulfurimonas and Acidithiobacillus) have been identified in the microbial mats (Ionescu et al., 2015a), and their metabolism may plausibly account for a local increase in $\mathrm{SO}_{4}^{2-}$ and concomitant gypsum precipitation. Likewise, sorption of $\mathrm{SO}_{4}^{2-}$ onto iron oxyhydroxides (Dzombak and Morel, 1990; originally described in soils) may be expected to occur in the microbial mats, and may further help to create locally distinct supersaturated microenvironments, thereby inducing gypsum precipitation. The gypsum lattice easily incorporates ions similar to $\mathrm{Ca}$ in charge and/or size, like Mg, K, Na, Cs, and Sr (e.g., Lu et al., 2002 and references therein) which may have contributed to the relative enrichment of these elements within the aged microbial mats (Figure 4). 


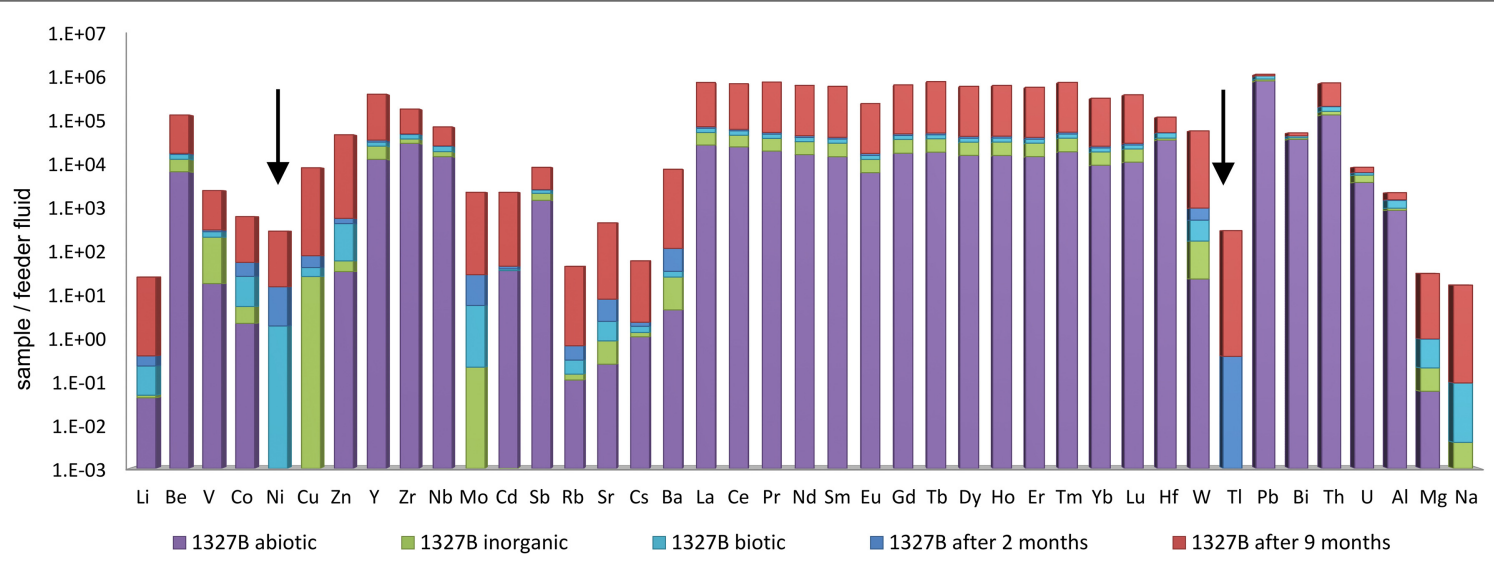

FIGURE 8 | Comparison of the TREE (normalized on the feeder fluid at 1327B) accumulated in the microbial and the artificial iron oxyhydroxides. Note that $\mathrm{Ni}$ and $\mathrm{Tl}$ are present only in the microbial iron oxyhydroxides including the biotic mineral precipitates (arrows).

Anoxic micro-environments may also provide an explanation for the observed formation of siderite, as this mineral is only stable under reducing conditions. Although SI values calculated for $\mathrm{FeCO}_{3}$ ranged between -0.44 and 0.14 for each flow reactor, siderite formation in the microbial mats was observed at both sites and during all time points.

When normalized on PAAS (Post-Archaean average Australian sedimentary rock; McLennan, 1989), the REE+Y plots of the feeder fluids and the microbial iron oxyhydroxides show a slight enrichment of the heavy REE (Gd-Lu+Y) over the light REE (La$\mathrm{Eu}$ ) (Figure 6). This pattern is characteristic for REE+Y bound in carbonate complexes, and is often referred to as "hydrogenous" (Takahashi et al., 2002). The phenomenon has been explained by different chemical complex formation of the REE $+Y$ in aqueous solutions, rather than a merely charge- and radius-controlled behavior (CHARAC; Bau, 1996; Takahashi et al., 2002).

When normalized on the feeder fluids, the REE+Y patterns of the microbial iron oxyhydroxides exactly mirror the source, thus displaying a consistent radius-independent fractionation (Figure 6). Interestingly, published REE patterns of Archaean BIFs (Bau and Dulski, 1996; Frei et al., 2008) range well-within the REE $+Y$ patterns of the microbial iron oxyhydroxides formed in our experiment (Figure 7). The only "outlier" is the positive $\mathrm{Eu}$ anomaly of BIFs, which is most likely due to hydrothermal influence (Michard and Albarède, 1986; Frei et al., 2008) and is missing in the feeder fluids and in the iron oxyhydroxides from Äspö. However, this coincidence may not be interpreted in terms of a "biosignature," because artificial precipitation of iron oxyhydroxides (1. inorganic 2. abiotic; 3. biotic, i.e., biological activity allowed for 15 days) from the Äspö feeder fluids resulted in largely the same REE+Y pattern. Likewise, the $\sim 10^{4}$ fold REE $+Y$ enrichments observed for the iron oxyhydroxides of the young (2-months old) microbial mats are quantitatively similar to the values observed for the artificial precipitates (Figure 7). Therefore, our data indicate that it is not possible to deduce a microbial contribution to the deposition of BIFs from REE+Y patterns. This is in agreement with a recent study on biotic vs. abiotc iron oxidation indicating that the presence of particulate organic matter or previously precipitated iron both accelerate further precipitation (Ionescu et al., 2015b).

Apart from the REE $+\mathrm{Y}$ distributions, a comparison of the complete TREE patterns of the artificial precipitates and the microbial iron oxyhydroxides yielded interesting results.

Cd was accumulated in small amounts in the biogenic iron oxyhydroxides and was highest in the abiotic precipitates. It was not detected at all in the inorganic iron oxyhydroxides. Although Cd does not show a preferential sorption to organic matter (Davis, 1984), in our study Cd is positively correlated to the organic matter containing iron oxyhydroxides. $\mathrm{Tl}$ was only observed in the microbial iron oxyhydroxides from the flow reactors. A biological function has not been reported so far, but $\mathrm{Tl}$ isotope patterns were suggested as a proxy for an increase in organic carbon burial in Paleocene marine Fe-Mn Crusts (Rehkämper et al., 2004; Nielsen et al., 2009).

$\mathrm{Ni}$ was only detectable, and accumulated, in microbial iron oxyhydroxides (all samples from 15 days, 2 and 9 months) growth. $\mathrm{Ni}$ is known to fulfill a range of biological functions, especially in Ni-metalloenzymes. Prominent examples are CO dehydrogenase, acetyl-CoA synthetase, and methyl-coenzyme $M$ reductase which all play important roles in microbial carbon metabolism (Ermler et al., 1998; Dobbek et al., 2001; Voordouw, 2002; Ragsdale, 2007). The presence of $\mathrm{Ni}$ in the biogenic precipitates may thus be inherited from the Ni-content of living microbial cells. Although Ni is constantly accumulated in the microbial iron oxyhydroxides, the molar $\mathrm{Ni} / \mathrm{Fe}$ ratio decreased by an order of magnitude (from $2.8 \times 10^{-5}$ and $8.0 \times 10^{-6}$ to $3.0 \times 10^{-6}$ and $2.0 \times 10^{-6}$ ) with the aging of the mats at both sites, possibly indicating a lower contribution of microbial cellular matter to the metal content of the late precipitates. It has been proposed, that BIFs mirror the source fluid from which they were precipitated and thus, the elemental composition of the Precambrian Ocean (Konhauser et al., 2009). In our study, however, the decreasing molar $\mathrm{Ni} / \mathrm{Fe}$ ratios of microbial iron oxyhydroxides are not representative for the constant $\mathrm{Ni} / \mathrm{Fe}$ supply that was delivered from the feeder fluids. 


\section{CONCLUSIONS}

In a suboxic aquifer system hosted by granodioritic rocks and influenced by Baltic Sea water, the development of iron oxidizing microbial mats was studied to test the potential usage of TREE as biosignatures for a microbial involvement in Fe mineral precipitation. Over the 9 months of the experiment, massive ironoxidizing microbial mat systems developed whose predominant FeOB were the stalk-forming Mariprofundus sp. and Gallionella sp. The deposition of iron oxyhydroxides in these mat systems was initially controlled by the metabolic activity of Mariprofundus sp. and Gallionella sp. and passive mineralization caused by the high biosorption capacity of newly formed EPS-stalks. Upon aging, ongoing iron oxyhydroxide impregnation caused a gradual decrease of the biosorption capacities of the EPS-stalks. As a result, indirect mineral precipitation became increasingly important over time.

The iron-oxidizing microbial mats proved to be extremely efficient in the accumulation of trace and rare earth elements (TREE), leading to massive (up to $10^{6}$-fold) enrichments of individual metals in the microbial iron oxyhydroxides. The REE+Y patterns of the resulting microbial iron oxyhydroxides matched quite closely the feeding aquifer, as well as Archaean Banded Iron Formations (BIFs). However, inorganic and abiotic iron oxyhydroxides precipitated artificially from the Äspö feeder fluids showed a very similar REE $+Y$ pattern and roughly the same accumulation rates as the biogenic deposits formed in the flow reactors. These results argue against the usage of $\mathrm{REE}+\mathrm{Y}$ patterns to deduce a biological contribution of FeOB to the deposition of BIFs. On the other hand, the microbial iron oxyhydroxides showed significant accumulations of the trace elements $\mathrm{Ni}$ and $\mathrm{Tl}$ which were absent in the artificially precipitated iron oxyhydroxides. These elements should be studied further as potential candidate biosignatures to assess a biological contribution of FeOB to the deposition of BIFs.

\section{ACKNOWLEDGMENTS}

We acknowledge with gratitude the detailed and constructive comments provided by Doug LaRowe and Jakob Zopfi. We are also grateful to Emmeli Johansson, Magnus Kronberg, Teresita Morales and the SKB staff for technical, logistic and analytical support at the Äspö HRL. Volker Karius and Veit-Enno Hoffmann, Erwin Schiffzyk, and Dorothea Hause-Reitner are acknowledged for their assistance with the XRD, ICP-OES, and SEM-EDX measurements, respectively. Andreas Pack helped to improve the data presentation. Our study received financial support from the German Research Foundation (DFG). This is publication No. 75 of the DFG Research Unit FOR 571 "Geobiology of Organo- and Biofilms."

\section{REFERENCES}

Anbar, A. D., Duan, Y., Lyons, T. W., Arnold, G. L., Kendall, B., Creaser, R. A., et al. (2007). A whiff of oxygen before the Great Oxidation Event? Science 317, 1903-1906. doi: 10.1126/science.1140325

Anderson, C. R., and Pedersen, K. (2003). In situ growth of Gallionella biofilms and partitioning of lanthanides and actinides between biological material and ferric oxyhydroxides. Geobiology 1, 169-178. doi: 10.1046/j.1472-4669.2003.00013.x

Bau, M. (1996). Controls on the fractionation of isovalent trace elements in magmatic and aqueous systems: evidence from $\mathrm{Y} / \mathrm{Ho}, \mathrm{Zr} / \mathrm{Hf}$, and lanthanide tetrad effect. Contrib. Mineral Petrol. 123, 323-333. doi: 10.1007/s004100050159
Bau, M. (1999). Scavening of dissolved yttrium and rare earths by precipitating iron oxyhydroxide: experimental evidence for Ce oxidation, Y-Ho fractionation, and lanthanide tetrade effect. Geochim. Cosmochim. Acta 63, 67-77. doi: 10.1016/S0016-7037(99)00014-9

Bau, M., and Dulski, P. (1996). Distribution of yttrium and rare-earth elements in the Penge and Kuruman iron-formations, Transvaal Supergroup, South Africa. Precambrian Res. 79, 37-55. doi: 10.1016/0301-9268(95)00087-9

Bau, M., and Möller, P. (1993). Rare earth element systematics of the chemically precipitated component in early precambrian iron-formations and the evolution of the terrestrial atmosphere-hydrosphere-lithosphere system. Geochim. Cosmochim. Acta 57, 2239-2249. doi: 10.1016/0016-7037(93)90566-F

Bazylinski, D. A., Frankel, R. B., and Konhauser, K. O. (2007). Modes of biomineralization of magnetite by microbes. Geomicrobiol. J. 24, 465-475. doi: 10.1080/01490450701572259

Cao, M., Li, Z., Wang, J., Ge, W., Yue, T., Li, R., et al. (2012). Food related applications of magnetic iron oxide nanoparticles: enzyme immobilization, protein purification, and food analysis. Trends Food Sci. Technol. 27, 47-56. doi: 10.1016/j.tifs.2012.04.003

Chan, C. S., Fakra, S. C., Edwards, D. C., Emerson, D., and Banfiled, J. F. (2009). Iron oxyhydroxide mineralization of microbial extracellular polysaccharides. Geochim. Cosmochim. Acta 73, 3807-3818. doi: 10.1016/j.gca.2009.02.036

Chan, C. S., Fakra, S. C., Emerson, D., Fleming, E. J., and Edwards, K. J. (2011). Lithotrophic iron-oxidizing bacteria produce organic stalks to control iron mineral growth: implications for biosignature formation. ISME J. 5, 717-727. doi: 10.1038/ismej.2010.173

Chi Fru, E., Piccinelli, P., and Fortin, D. (2012). Insights into the global microbial community structure associated with iron oxyhydroxide minerals deposited in the aerobic biogeosphere. Geomicrobiol. J. 29, 587-610. doi: 10.1080/01490451.2011.599474

Comolli, L. R., Luef, B., and Chan, C. S. (2011). High-resolution 2D and 3D cryo-TEM reveals structural adaptations of two stalk-forming bacteria to an Fe-oxidizing lifestyle. Environ. Microbiol. 13, 2915-2929. doi: 10.1111/j.14622920.2011.02567.x

Cornell, M., and Schwertmann, U. (2003). The Iron Oxides. Weinheim: Wiley VCHVerlag GmbH \& Co. doi: 10.1002/3527602097

Davis, J. A. (1984). Complexation of trace metals by adsorbed natural organic matter. Geochim. Cosmochim. Acta 48, 679-691. doi: 10.1016/0016-7037(84) 90095-4

de Carlo, E. H., Wen, X.-Y., and Irving, M. (1998). The influence of redox reactions on the uptake of dissolved Ce by suspended Fe and Mn oxide particles. Aquat Geochem. 3, 257-289.

Dobbek, H., Svetlitchnyi, V., Gremer, L., Huber, R., and Meyer, O. (2001). Crystal structure of a carbon monoxide dehydrogenase reveals a [Ni-4Fe-5S] cluster. Science 293, 1281. doi: 10.1126/science. 1061500

Dzombak, D., and Morel, F. M. (1990). Surface Complexation Modelling: Hydrous Ferric Oxide. New York, NY: Wiley and Sons.

Ehrenberg, C. G. (1836). Vorläufige mitteilungen über das wirkliche vorkommen fossilier infusorien und ihre große verbreitung. Pogg. Ann. Phys. Chem. 38, 213-227. doi: 10.1002/andp.18361140520

Emerson, D., Rentz, J. A., Lilburn, T. G., Davis, R. E., Aldrich, H., Chan, C., et al. (2007). A novel lineage of proteobacteria involved in formation of marine Fe-oxidizing microbial mat communities. PLOS ONE 2:e667. doi: 10.1371/journal.pone.0000667

Ercole, C., Cacchio, P., Botta, A. L., Centi, V., and Lepidi, A. (2007). Bacterially induced mineralization of calcium carboante: the role of exopolysaccharides and capsular polysaccharides. Microsc. Microanal. 13, 42-50. doi: $10.1017 /$ S1431927607070122

Ermler, U., Grabarse, W., Shima, S., Goubeaud, M., and Thauer, R. K. (1998). Active sites of transition metal enzymes with focus on nickel. Curr. Opin. Struct. Biol. 8, 749-756. doi: 10.1016/S0959-440X(98) 80095-X

Ferris, F. G., Hallberg, R. O., Lyvén, B., and Pedersen, K. (2000). Retention of strontium, cesium, lead and uranium by bacterial iron oxides from subterranean environment. Appl. Geochem. 15, 1035-1042. doi: 10.1016/S08832927(99)00093-1

Ferris, F. G., Kohnhauser, K. O., Lyvén, B., and Pedersen, K. (1999). Accumulation of metals by bacteriogenic iron oxides in a subterranean environment. Geomicrobiol. J. 16, 181-192. doi: 10.1080/014904599 270677 
Fortin, D., and Beveridge, T. J. (1997). Role of the bacterium Thiobacillus in the formation of silicates in acidic mine tailings. Chem. Geol. 141, 235-250. doi: 10.1016/S0009-2541(97)00069-7

Fortin, D., Ferris, F. G., and Beveridge, T. J. (1997). "Surface-mediated mineral development by bacteria," in Geomicrobiology: Interactions Between Microbes and Minerals, Reviews in Geomicrobiology, Vol. 35, ed P. H. Ribbe (Chantilly, VA: Mineralogical Society of America), 161-180.

Frankel, R. B., and Bazylinski, D. A. (2003). "Biologically induced mineralization by bacteria," in Biomineralization, Reviews in Mineralogy and Geochemistry, Vol. 54, eds P. M. Dove. J. J. de Yoreo, and S. Weiner (Chantilly, VA: Mineralogical Society of America), 95-114.

Frei, R., Dahl, P. S., Duke, E. F., Frei, K. M., Hansen, T. R., Fransson, M. M., et al. (2008). Trace element and isotopic characterisation of Neoarchean and Paleoproterozoic formations in the Black Hills (South Dakota, USA): assessment of chemical change during 2.9-1.9 Ga deposition bracketing the 2.4-2.2 Ga first rise of atmospheric oxygen. Precambrian Res. 162, 441-474. doi: 10.1016/j.precamres.2007.10.005

Gadd, G. M. (2010). Metals, minerals and microbes: geomicrobiology and bioremediation. Microbiology 156, 609-643. doi: 10.1099/mic.0.037143-0

Haferburg, G., and Kothe, E. (2007). Microbes and metals: interactions in the environment. J. Basic Microbiol. 47, 453-467. doi: 10.1002/jobm.2007 00275

Haferburg, G., Merten, D., Büchel, G., and Kothe, E. (2007). Biosorption of metal and salt tolerant microbial isolates from a former uranium mining aerea. Their impact on changes in rare earth element patterns in acid mine drainage. J. Basic Microbiol. 47, 474-484. doi: 10.1002/jobm.200700256

Hallbeck, L., and Pedersen, K. (1991). Autotrophic and mixothrophic growth of Gallionella ferruginea. J. Gen. Microbiol. 137, 2657-2661. doi: 10.1099/00221287-137-11-2657

Hallbeck, L., and Pedersen, K. (1995). Benefits associated with the stalk of Gallionella ferruginea, evaluated by comparison of a stalk-forming and nonstalk-forming strain and biofilm studies in situ. Microbiol. Ecol. 30, 257-268. doi: 10.1007/BF00171933

Hallbeck, L., Ståhl, F., and Pedersen, K. (1993). Phylogeny and phenotypic characterization of the stalk-formin and iron oxidizing bacterium Galionella ferruginea. J. Gen. Microbiol. 139, 1531-1535. doi: 10.1099/00221287-139-7-1531

Hallberg, R., and Ferris, F. G. (2004). Biomineralization by Gallionella. Geomicrobiol. J. 21, 325-330. doi: 10.1080/01490450490454001

Hansen, H. P. (1999). “Determination of oxygen," in Methods of Seawater Analysis, eds K. Grasshoff, K. Kremling, and M. Ehrhardt (Weinheim: Wiley VCH-Verlag $\mathrm{GmbH} \& \mathrm{Co}), 75-89$.

Ionescu, D., Heim, C., Polerecky, L., Ramette, A., Haeusler, S., Bizic-Ionescu, M., et al. (2015a). Diversity of iron oxidizing and reducing bacteria in flow reactors in the Äspö Hard Rock Laboratory. Geomicrobiol. J. doi: 10.1080/01490451.2014.884196. (in press).

Ionescu, D., Heim, C., Polerecky, L., Thiel, V., and De Beer, D. (2015b). Biotic and abiotic oxidation and reduction of iron at circumneutral $\mathrm{pH}$ are inseparable processes under natural conditions. Geomicrobiol. J. doi: 10.1080/01490451.2014.887393. (in press).

Ionescu, D., Siebert, C., Polerecky, L., Munwes, Y. Y., Lott, C., Háusler, S., et al. (2012). Microbial and chemical characterization of underwater fresh water springs in the Dead Sea. PLoS ONE 7:e38319. doi: 10.1371/journal.pone.0038319

Kappler, A., Straub, B., and Newman, D. K. (2005). Fe(III) mineral formation and cell incrustation by the nitrate-dependent $\mathrm{Fe}(\mathrm{II})$-oxidizer strain BoFeN1. Geobiology 3, 235-245. doi: 10.1111/j.1472-4669.2006.00056.x

Katsoyiannis, I. A., and Zouboulis, A. I. (2006). Use of iron- and manganeseoxidizing bacteria for the combined removal of iron, manganese and arsenic from contaminated groundwater. Water Qual. Res. J. Can. 41, 117-129. Available online at: https://www.cawq.ca/journal/temp/article/296.pdf

Kennedy, D. B., Scott, S. D., and Ferris, F. G. (2004). Hydrothermal phase stablization of 2-line ferrihydrite by bacteria. Chem. Geol. 212, 269-277. doi: 10.1016/j.chemgeo.2004.08.017

Konhauser, K. O. (1997). Bacterial iron biomineralization in nature. FEMS Microbiol. Rev. 20, 315-326. doi: 10.1111/j.1574-6976.1997.tb00317.x

Konhauser, K. O., Hamade, T., Raiswell, R., Morris, R. C., Ferris, F. G., Southam, G., et al. (2002). Could bacteria have formed the Precambrian banded iron formations? Geology 20, 1079-1082. doi: 10.1130/0091-7613(2002)030<1079:CBHFTP>2.0.CO;2
Konhauser, K. O., Pecoits, E., Lalonde, S. V., Papineau, D., Nisbet, E. G., Barley, M. E., et al. (2009). Oceanic nickel depletion and a methanogen famine before the Great Oxidation Event. Nature 458, 750-754. doi: 10.1038/nature07858

Krapez, B., Barley, M. E., and Pickard, A. L. (2003). Hydrothermal and resedimented origins of the precursor sediments to banded iron formation: sedimentological evidence from the Early Paleoproterozoic Brockman Supersequence of Western Australia. Sedimentology 50, 979-1011. doi: 10.1046/j.13653091.2003.00594.x

Laaksoharju, M., Tullborg, E.-L., Wikberg, P., Wallin, B., and Smellie, J. (1999). Hydrogeochemical conditions and evolution at the Äspö HRL, Sweden. Appl. Geochem. 14, 835-859. doi: 10.1016/S0883-2927(99)00023-2

Lane, D. J. (1991). "16S/23S rRNA sequencing," in Nucleic Acid Techniques in Bacterial Systematics, eds E. Stackebrandt and M. Goodfellow (New York, NY: Wiley), 115-175.

Lewy, Z. (2012). Banded Iron Formations (BIFs) and associated sediments do not reflect the physical and chemical properties of early precambrian seas. Int. J. Geosci. 3, 226-236. doi: 10.4236/ijg.2012.31026

Lin, P., Chen, M., and Guo, L. (2014). Effect of natural organic matter on the adsorption and fractionation of thorium and protactinium on nanoparticles in seawater. Mar. Chem. doi: 10.1016/j.marchem.2014.08.006. (in press).

Lu, F. H., Meyers, W. J., and Hanson, G. N. (2002). Trace elements and environmental significance of Messinian gypsum deposits, the Nijar Basin, southeastern Spain. Chem. Geol. 192, 149-161. doi: 10.1016/S0009-2541(02) 00009-8

McLennan, S. M. (1989). "Rare earth elements in sedimentary rocks: influence of provenance and sedimentary processes," in Geochemistry and Mineralogy of Rare Earth Elements, Reviews in Mineralogy, eds B. R. Lipin and G. A. McKay (Chantilly, VA: Mineralogical Society of America), 169-200.

Michard, A., and Albarède, F. (1986). The REE content of some hydrothermal fluids. Chem. Geol. 55, 51-60. doi: 10.1016/0009-2541(86)90127-0

Michel, M. F., Ehm, L., Antao, S. M., Lee, P. L., Chupas, P. J., Liu, G., et al. (2007). The structure of ferrihydrite, a nanocycrstalline material. Science 316, 1726-1729. doi: 10.1126/science. 1142525

Morgan, B., and Lahav, O. (2007). The effect of $\mathrm{pH}$ on the kinetics of spontaneous $\mathrm{Fe}(\mathrm{II})$ oxidation by $\mathrm{O} 2$ in aqueous solution - basic principles and a simple heuristic description. Chemosphere 68, 2080-2084. doi: 10.1016/j.chemosphere.2007.02.015

Morris, R. C., and Horwitz, R. C. (1983). The origin of the iron-formation-rich Hamersley Group of Western Australia - Deposition on a platform. Precambrian Res. 21, 273-297. doi: 10.1016/0301-9268(83)90044-X

Nielsen, S. G., Mar-Gerrison, S., Gannoun, A., LaRove, D., Klemm, V., Halliday, A. N., et al. (2009). Thallium isotope evidence for a permanent increase in marine organic carbon export in the early Eocene. Earth Planet Sci. Lett. 278, 297-307. doi: 10.1016/j.epsl.2008.12.010

Pedersen, K. (1997). Microbial life in deep granitic rock. FEMS Microbiol. Rev. 20, 399-414. doi: 10.1111/j.1574-6976.1997.tb00325.x

Pedersen, K. (2012). Subterranean microbial populations metabolize hydrogen and acetate under in situ conditions in granitic groundwater at $450 \mathrm{~m}$ depth in the Äspö Hard Rock Laboratory, Sweden. FEMS Microbiol. Ecol. 81, 217-229. doi: 10.1111/j.1574-6941.2012.01370.x

Pedersen, K., and Ekendahl, S. (1990). Distribution and activity of bacteria in deep granitic groundwaters of southeastern Sweden. Microbiol. Ecol. 20, 37-52. doi: 10.1007/BF02543865

Quast, C., Pruesse, E., Yilmaz, P., Gerken, J., Schweer, T., Yarza, P., et al. (2013). The SILVA ribosomal RNA gene database project: improved data processing and web-based tools. Nucleic Acids Res. 41, D590-D596. doi: 10.1093/nar/gks1219

Ragsdale, S. W. (2007). Nickel and the carbon cycle. J. Inorg. Biochem, 101, 1657-1666. doi: 10.1016/j.jinorgbio.2007.07.014

Rehkämper, M., Frank, M., Hein, J. R., and Halliz', A. (2004). Cenozoic marine geochemistry of thallium deduced from isotopic studies of ferromanganese crusts and pelagic sediments. Earth Planet Sci. Lett. 219, 77-91. doi: 10.1016/S0012821X(03)00703-9

Saini, G., and Chan, C. S. (2013). Near-neutral surface charge and hydrophilicity prevent mineral encrustation of Fe-oxidizing microorganisms. Geobiology 11, 191-200. doi: 10.1111/gbi.12021

Savchenko, A. G., Salikhov, S. V., Yurtov, E. V., and Yagodkin, Y. D. (2013). Application of Mössbauer spectroscopy for the complex structural analysis of iron oxide-based nanomaterials. Bull. Russ. Acad. Sci. Phys. 77, 704-709. doi: $10.3103 /$ S1062873813060282 
Schwertmann, U., Friedl, J., and Stanjek, H. (1999). From Fe(III) ions to ferrihydrite and then to hematite. J. Colloid Interf. Sci. 209, 215-223. doi: 10.1006/jcis. 1998.5899

Southam, G. (2000). "Bacterial surface-mediated mineral formation," in Environmental Microbe-Mineral Interactions, ed D. R. Lovley (Washington DC: ASM Press), 257-276. doi: 10.1128/9781555818098.ch12

Stumm, W., and Morgan, J. J. (1996). Aquatic Chemistry: Chemical Equilibria and Rates in Natural Waters. New York, NY: John Wiley \& Sons.

Takahashi, Y., Hirata, T., Shimizu, H., Ozaki, T., and Fortin, D. (2007). A rare earth element signature of bacteria in natural waters. Chem. Geol. 244, 569-583. doi: 10.1016/j.chemgeo.2007.07.005

Takahashi, Y., Yoshida, H., Sato, N., Hama, K., Yusa, Y., and Shimizu, H. (2002). Wand M-type tetrad effects in REE patterns for water-rock systems in the Tono uranium deposit, central Japan. Chem. Geol. 184, 311-335. doi: 10.1016/S00092541(01)00388-6

Thamdrup, B., Finster, K., Hansen, J. W., and Bak, F. (1993). Bacterial disproportionation of elemental sulfur coupled to chemical reduction of iron or manganese. Appl. Environ. Microbiol. 59, 101-108.

Thompson, J. B., and Ferris, F. G. (1990). Cyanobacterial precipitation of gypsum, calcite, and magnesite from natural alkaline lake water. Geology 18, 995-998.

Toner, B. M., Berqúo, T. S., Michel, F. M., Sorensen, J. V., Templeton, A. S., and Edwards, K. J. (2012). Mineralogy of iron microbial mats from Loihi Seamount. Front. Microbiol 3:118. doi: 10.3389/fmicb.2012.00118

Urrutia, M. M., and Beveridge, T. J. (1993). Mechanism of silicate binding to the bacteria cell wall in Bacillus subtilis. J. Bacteriol. 175, 1936-1945.

Voordouw, G. (2002). Carbon monoxide cycling by Desulfovibrio vulgaris Hildenborough. J. Bacteriol. 184, 5903-5911. doi: 10.1128/JB.184.21.5903 5911.2002
Wahlgren, C.-H., Hermanson, J., Forssberg, O., Curtis, P., Triumf, C.-A., Drake, H., et al. (2006). Geological Description of Rock Domains and Deformation Zones in the Simpevarp and Laxemar subareas. Preliminary Site Description Laxemar Subarea - Version 1.2, Svensk Kärnbränslehantering AB R-05-69.

Weiner, S., and Dove, P. M. (2003). "An overview of biomineralization processes and the problem of the vital effect," in Biomineralization, eds P. M. Dove, J. J. De Yoreo, and S. Weiner (Chantilly, VA: Mineralogical Society of America), 1-29.

Conflict of Interest Statement: The authors declare that the research was conducted in the absence of any commercial or financial relationships that could be construed as a potential conflict of interest.

Received: 19 October 2014; paper pending published: 16 November 2014; accepted: 03 February 2015; published online: 24 February 2015.

Citation: Heim C, Simon K, Ionescu D, Reimer A, De Beer D, Quéric N-V, Reitner J and Thiel V (2015) Assessing the utility of trace and rare earth elements as biosignatures in microbial iron oxyhydroxides. Front. Earth Sci. 3:6. doi: 10.3389/feart. 2015.00006

This article was submitted to Biogeoscience, a section of the journal Frontiers in Earth Science.

Copyright (c) 2015 Heim, Simon, Ionescu, Reimer, De Beer, Quéric, Reitner and Thiel. This is an open-access article distributed under the terms of the Creative Commons Attribution License (CC BY). The use, distribution or reproduction in other forums is permitted, provided the original author(s) or licensor are credited and that the original publication in this journal is cited, in accordance with accepted academic practice. No use, distribution or reproduction is permitted which does not comply with these terms. 